\title{
Population Change and International and Internal Migration in Italy, 2002-2017: Ravenstein Revisited*
}

\author{
Federico Benassi, Corrado Bonifazi, Frank Heins, Francesca Licari, \\ Enrico Tucci
}

\begin{abstract}
In 1885, Ravenstein formulated his "laws" of migration, based on the experience of the British Isles. In a further 1889 paper, he extended his analysis as a tour d'horizon of migration and population changes in other nations, including Italy. Even if social and economic processes including globalisation and rising mobility have changed the world since then, Ravenstein's "Iaws" remain a point of reference today. Harnessing theoretical and methodological advances made since the 19th century, this paper describes and seeks to explain the role of international and internal migration in regional population change in Italy from 2002-2017. This paper provides the first geographically detailed migration analysis for the country's 611 Local Labour Market Areas (LLMAs), using register-based migration and population data. Our contribution focuses on several of Ravenstein's "laws" relating to gender (differences between men and women), natives and non-natives (differences between the Italian and the foreign population), distance migrated from origin to destination, and the role of the economy in shaping push and pull factors of migration. The results show that international migration is more prominent among men than women. In the case of internal moves, the rates of migration among men and women are similar, and internal migration is more prominent among the foreign than the native Italian population. Overall, international migration gains contribute substantially more to population change than internal migration gains and losses do. In Italy, the effects of persistent economic imbalances and of distance on migration patterns are not in line with Ravenstein's hypotheses: not all areas with high unemployment show an effect of dispersion, nor does distance always act as a deterrent to migration. The geographically detailed analysis presented here illustrates the temporal and spatial coexistence of diverse international and internal migration processes depending on local characteristics, as well as the importance of the economic or administrative centres as the driving force behind national patterns. Our results show that, even 130 years after their formulation, Ravenstein's migration "laws" (more accurately
\end{abstract}

This article belongs to a special issue on "Internal Migration as a Driver of Regional Population Change in Europe: Updating Ravenstein". 
called "hypotheses" today) are still a valuable starting point in assessing and understanding migration processes and their role in regional population change.

Keywords: Internal migration - International migration - Population redistribution • Socio-economic factors · Italy · Local Labour Market Areas

\section{Introduction}

Ernst Georg Ravenstein's work (1876, 1885 and 1889) laid the foundations for many of the theories of migration we know today. Whereas Ravenstein formulated the "laws" in his 1885 paper using data for the British Isles, his 1889 paper attempted to verify whether these "laws" also held in the context of the contemporary political entities of continental Europe and North America. Ravenstein's work continues to be influential and can be found in most of the theoretical approaches and interpretative models on internal and international migration (for example, Lee 1966; Tobler 1995; Piché 2013; Stil/well/Thomas 2016). The gravitational approach, rural-urban migration and urbanisation, the relationship between migration and development, the two-way dynamics of migration (net migration and return migration), the gendering of migration, and the economic determinants of migration are only some of the most relevant issues that are based on Ravenstein's seminal works (King 2012).

Ravenstein also understood that the forces underlying migratory movements were "complex and include the quality of the public infrastructure, such as roads, climate, taxation and more" (Greenwood 2019: 269). The validity of Ravenstein's laws has been tested in numerous contributions. Macisco and Pryor (1963), for example, used the laws to provide a framework to review the many studies of migration in the USA. More recent studies have focused on some points directly related to Ravenstein's hypotheses, such as the differentials in mobility between women and men, underlining the importance of available data and the historical context in the formulation of the "laws" of migration. For example, Alexander and Steidl (2012) show that Ravenstein's affirmation that women are more migratory is based on, for Ravenstein, hidden age structure differences for men and women due to differences in mortality and out-migration. However, Ravenstein himself answered his critics: "Of course I am perfectly aware that our laws of population, and economic laws generally, have not the rigidity of physical laws, as they are continually being interfered with by human agency." (1989: 241). The direct and indirect presence of Ravenstein's "laws" and ideas in the actual academic discussion show that empirical migration studies are not imaginable without the foundations laid by Ravenstein in his contributions. Clearly, after more than 130 years and fundamental changes in social and economic processes, as well as increasing globalisation and mobility, not all of Ravenstein's observations can be confirmed, and it seems easy to find exceptions to the "rules". 
In this paper we investigate whether the pioneering statements by Ravenstein remain relevant for the analysis of migration in Italy from a geographically detailed perspective, focussing on the period 2002-2017. In Italy, internal and international migration contributed decisively to demographic change and population growth. Nevertheless, partially brought on by the Great Recession after 2008, the role of international migration diminished and, as a consequence, total population decreased slightly after 2014 . The relation between migration and population change has become complex and diversified at the geographic level, especially when focussing on Local Labour Market Areas (LLMAs) as units of analysis.

In the Italian context, a subset of the Ravenstein "laws" (1885) is particularly relevant: the differences between men and women and the differences, between the Italian and the foreign population regarding international and internal migration processes, as well as his observations regarding the role of distance and the importance of economic context. In Italy, differences in the roles and opportunities of women and men remain important. Similarly, the presence of foreigners in Italy is a current and relevant phenomenon, not least because of the significant sociodemographic differences between foreigners and Italians. Finally, Italy continues to be characterised by a high degree of heterogeneity in socio-economic regional development and accessibility.

The paper will examine these premises in four further sections. First, it gives an overview of the post-war international and internal migration trends in Italy (Section 2). It then presents the data and methods (Section 3) and puts some of Ravenstein's "laws" through an Italian checklist, underlining the nexus between migration and population change (Section 4). The concluding section summarises the findings (Section 5).

\section{Post-war international and internal migration trends in Italy}

Internal migration has always played a major social and economic role in Italy, but the peak of its importance was certainly achieved in the years of the economic boom of the 1950s and 1960s, with important long-distance migration flows originating in the Northeast and the South of Italy and directed to the industrial areas of the Northwest and to Rome (Bonifazi 2013a; Gallo 2012; Golini 1974). The internal movements of the period after the Second World War are linked to the massive economic and demographic growth of urban areas. This growth was to the detriment of rural areas, including the Apennines (the 1,200 km mountain range that stretches from the Northwest to the South), and the Mezzogiorno (the Southern regions of Italy including the islands of Sardinia and Sicily). It was partly determined by the Fordist economic model that generated a strong demand for a young workforce in the factories of the industrial triangle of the Northwest. In this period the migration flows between the Mezzogiorno and the Centre-North and the resulting net migration balance in favour of the Centre-North became one of the most important characteristics of the Italian internal migration pattern, attracting the attention of 
academic and political debate with many analyses focusing on the subordinate position of the Mezzogiorno (Bonifazi 2013b; Impicciatore/Strozza 2016, for example).

With the decline of the Fordist model and with the oil price crises of the 1970s, internal mobility decreased and net migration patterns changed. The economic recovery of the 1980s and the development of the Third Italy led to a shift of the net migration patterns away from the Industrial Triangle of the Northwest to the Third Italy with its smaller and often family-led companies. This created economic well-being in extended areas of Central and Northeastern Italy, such as the cities along the Via Aemilia, a Roman road in Northern Italy from Rimini on the Adriatic coast to Piacenza. However, this did not cause a new rise in internal migration flows, since the production processes were not particularly labour-intensive and local labour supply increased, especially through the higher labour market participation of women. The slight increase in internal migration in the 1990s was mainly driven by short-distance movements, even though the flows between the South and the other Italian territorial divisions continued to be important.

However, the main novelty of Italian internal mobility in the last thirty years has been the growing role of the foreign population (Bonifazi et al. 2009, 2016, 2017, 2020, Gallo 2012) with its higher propensity to change residence (Bonifazi et al. 2012; De Filippo/Strozza 2011), even if immigration has declined in recent years. The higher internal mobility of the foreign population is probably due to the intertwined dynamics of their international and internal migration and to being exposed to greater uncertainty regarding housing and employment.

As matter of fact, in the last decades, foreign immigration was unexpectedly the main novelty of Italy's demographic profile and the most important characteristic of the Italian migration system. The growth of the foreign population has been substantial: from 0.22 million in 1981 to 5.26 million at the end of 2018. As a result of this considerable migratory inflow, the total population continued to grow until reaching 60.8 million in early 2015, notwithstanding the low fertility. At the regional level, the foreign population is mainly concentrated in the affluent Centre-North, which has also continued to benefit from internal migration from Southern Italy.

This paper follows a long tradition of studying a wide range of aspects of Italian internal migration processes and patterns in different academic disciplines, including demography, geography, sociology and economics. Bonifazi and Heins (2000) gave an overview of internal migration from a demographic point of view including also geographic aspects. Since then, several reviews of internal migration in Italy have been published. For example, Panichella (2012) offers a detailed review of the sociological contributions to the study of internal migration in Italy, confirming a selection process regarding education and social extraction of the migration flows between the South and the Centre-North. Several analyses of specific sociological aspects are found in Bubbico et al. (2011).

Results of interregional migration analysis of the Italian situation and the theoretical approaches from an economic point of view are presented, for example, by Biagi and Dotzel (2018) and Faggian et al. (2015). An econometric analysis of the Italian situation is offered by Biagi et al. (2011), analysing the internal migration flows between the 103 provinces in 2001-2002 and including economic, social and 
environmental variables. Distinguishing between short- and long-distance flows, Biagi et al. (2011) find different models and state that short-distance migration flows do not seem to be determined by economic variables, while in the case of longdistance migration flows, "economic/labour market variables play a dominant role" (Biagi et al. 2011: 123).

Piras (2017) offers a further review of the empirical economic literature on regional patterns of internal migration in Italy and finds that most studies confirm the role played by per capita GDP and unemployment rates as push and pull factors. The analysis covers a longer timeframe (1970-2005), uses the 20 Italian regions, and considers the push and pull factors separately since the variables could have different effects if considered at the origin or at the destination of the migration flow. Already in the 1990s, the absence of a geographic relationship between unemployment rates and internal migration was found "puzzling" (Faini et al. 1997), with a recent contribution elaborating on this aspect (Faggian et al. 2017). Several analyses focus on the relationship between international immigration in general and on foreign and Italian internal migration (see for example Mocetti/Porello 2010; Benassi et al. 2019). Basile et al. (2018) probe whether international migrants are complements or substitutes to the Italian workforce. They identify a displacement effect of foreign immigration for 2003-2011 regarding the foreign-born and the low-qualified (with a lower secondary, and especially primary, level of education) Italian population, as well as a complementary effect to the more highly educated Italian population.

The last twenty years have been characterised by a slight upturn of internal mobility that has been halted by the recent economic and financial crisis (Bonifazi et al. 2017). Notwithstanding the low internal migration intensities and the reduction of the positive international migration balance, the geographic net migration patterns of foreigners and Italians seem to have changed markedly over recent years.

\section{Data and methods}

In his work, Ravenstein used migration data by place of birth from the 1871 and 1881 British censuses, along with similar data from censuses in North America and Europe (Grigg 1977). The definition of the person as a migrant is taken from the information on the place at birth and the place of residence at the census dates. If the two places differ, the person is considered a migrant, though there is no data on when the migration actually took place. The data available to Ravenstein allowed a distinction to be drawn between international migration and an internal move. Ravenstein defined movements between adjacent counties as "short-distance" and showed that the majority of migrants only migrated in this manner.

The present analysis is based on data from the Italian population registers, using official statistics on migratory movements occurring from 2002-2017. The population registers are organised at the municipal level. Italy has almost 8,000 municipalities and every movement between them is counted in these registers. The population registers provide the information on migration flows that are recorded when an individual or a family registers a change of residence to the municipality 
of destination. This registration is obligatory and gives access to many administrative advantages (local or regional differences in taxes, fees, insurance rates etc.), so it is likely that the vast majority of individuals indeed register their migration. On the other hand, particular subgroups, such as students, are less inclined to communicate their (temporary) residence to the new municipality. For each change of address, information on the municipalities of origin and destination as well as the main socio-demographic information of the individual that changes residence (citizenship, place and date of birth, sex, marital status and educational attainment) is also available. In 2012, a specific law (Decree-Law February 9 ${ }^{\text {th }}, 2012$ N. 5, converted into law April $4^{\text {th }} 2012 \mathrm{~N}$. 35) led to the processing of the information on changes of residence in the municipal population registers almost in real time, with a noticeable reduction of the time elapsed between the request by the citizen and the final transmission of the information to the registers. This change in registration methods resulted in an overcount of moves in 2012, which is why the data for 2012 should be interpreted with great caution.

To provide spatially detailed analyses of the structure of migration flows in Italy, we use flow data for 611 Local Labour Market Areas (LLMAs) or Sistemi Locali del Lavoro. These areas were defined by Istat (2015) and express the organisation of the Italian national territory based on the relationships between individuals and the social and economic context. The LLMAs are based on the daily commuting patterns between the municipalities of residence and the place of work and define the urban systems where most of the daily activities and movements of people are concentrated, providing a grid whose boundaries derive from actual social and economic processes and not historic or geographic ones. The information on the daily commuting flows for work were collected in the $15^{\text {th }}$ Population and Housing Census, carried out in 2011 (/stat 2015). Until March 2018, Italy was divided into 611 LLLMAs: 225 in the North, 105 in the Centre, and 281 in the South and the Islands (or Mezzogiorno).

To facilitate the comparison of geographic patterns over time, the contribution focuses on two different periods: 2004-2008 and 2013-2017, divided by the effects of the great economic recession after 2008. In Italy, a second economic downturn followed in 2012 and 2013 and the country does not seem to have recovered fully in the years thereafter. Whereas the first period is characterised by a (slowly) growing economy, the second period is characterised by high unemployment in the aftermath of the economic crisis. We omit the years 2009 to 2012 in this comparison, since these are years of transition without clear regional patterns and because 2012 presents the abovementioned data situation.

The analysis of the role of migration for population change is based on net $\mathrm{mi}$ gration rates at the regional level and aggregate net migration rates (ANMRs) at the national level. The latter is used for the comparison of internal net migration over the entire study period (2002-2017). The aggregate rate is defined as ANMR $=100$ * $0.5 \Sigma i|\mathrm{Di}-\mathrm{Oi}| / \mathrm{P}(\mathrm{i})$, where the variables $\mathrm{Di}$ and $\mathrm{Oi}$ are inflows to and outflows from region $\mathrm{i}$, and $\mathrm{P}(\mathrm{i})$ is the population at risk in region $\mathrm{i}$ (Bell et al. 2002; Rees et al. 2017). The ANMR thus measures the impact of migration on population redistribution: it identifies the net shift of population between regions per hundred persons resident 
in the country. In a second part of the analysis, we focus on geographic differences and compare the two periods (2004-2008 and 2013-2017) based on net migration rates.

Annual citizenship, sex and age data by Istat and updated after the 2011 population census serve as the denominator for calculations of the rates (see http://demo. istat.it/ and http://demo.istat.it/ricostruzione2013/index.php). The net migration rates NMR (NMR $=100 *(\mathrm{Di}-\mathrm{Oi}) / \mathrm{P}(\mathrm{i})$, with the variables $\mathrm{Di}$ and Oi denoting inflows to and outflows from region $\mathrm{i}$, and $\mathrm{P}(\mathrm{i})$ as the average population at risk in region i) are calculated for the total population and by citizenship, sex and age groups. It should be noted that since the first years of the study period, the foreign population resident in Italy has grown significantly, growing from 1.5 million in 2003 to more than 5.2 million in 2019; 8.7 percent of the total population. This process goes hand in hand with an increasing number of naturalisations. Throughout this paper, the terms "Italian population" or "Italians" and "foreign population" or "foreigners" are used to distinguish the resident population by citizenship. In recent years, the number of naturalisations increased considerably, with a maximum of 185,000 in 2016.

When discussing distance, one important point is certainly the way distance is measured. Whereas in the past the geographic distance was the point of reference, distance can today be expressed in many other ways, including expenditures in money and time. We nonetheless prefer the distance between the geographic centres of the LLMAs for simplicity's sake.

Socio-economic indices were used to test the possible factors that influence the internal and international net migration rates (for a complete list, see Annex 2). The rates of economic activity and unemployment rates are annually estimated by Istat (see https://www.istat.it/it/archivio/217437). Other and more detailed socioeconomic information is drawn from the 2011 population census. In general, the geographic patterns of the indices are stable over time and a high collinearity is observed between indices. For example, the geographic differences of economic activity, unemployment, and the share of foreign population are very similar. This is not surprising given that Italy is a country divided into two macro-areas of economic well-being.

A further dimension includes population density, which is generally used to define settlement characteristics of the LLMAs and to describe processes of urbanisation (Champion 2001; Bonifazi/Heins 2003). Population density is the ratio between resident population of a territorial unit (here the LLMAs) and their surface area (expressed in square kilometres). In the Italian context, population density does not describe settlement characteristics and the process of urbanisation very effectively, as rural areas can also have a relatively high population density. Additional socio-economic information is therefore used to systematically describe the territorial differences in the Italian context. Regarding LLMA age structure, our main focus is on the share of the 20-44-year-olds, the age group with the highest migration intensities. The geographic differences in the age structure are the result of past patterns of demographic change, e.g. lower fertility rates in the Centre-North and higher ones in the Mezzogiorno, and more recent international immigration. The age structure patterns are only partially related to socio-economic disparities. Urbanity (defined 
as high proportions of university degree-holders and employment in sectors such as IT or financial services) is a less decisive socio-demographic and socio-economic aspect. The same holds for the late departure from the parental home, a specifically Southern European and Italian cultural aspect influencing internal migration patterns of the local population, is represented through the share of the 20-44-yearolds living in the same household as their parents. Population-weighted correlation coefficients are used to test for links between international and internal net migration patterns and these socio-economic indices.

Inspired by Ravenstein's work, this paper aims to provide further insights into the recent migration patterns in Italy by analysing the socio-demographic and geographic detail of international and internal net migration patterns. The analysis of internal migration considers the distance migrated and the abovementioned factors linked to the Italian settlement system and the economic situation that are hypothesised to influence the migration patterns at the level of the LLMAs.

\section{Ravenstein's seven "laws": an Italian checklist}

Our analysis of migration flows at the nation-wide scale and for selected case study regions aims to verify some of the "laws" observed by Ravenstein over the past 20 years for the Italian context.

Ravenstein's seven "laws" (1885: 198-199) are:

1. "... the great body of our migrants only proceed a short distance" forming "'currents of migration' setting in the direction of the great centres of commerce and industry which absorb the migrants."

2. Migration is leading to population gain through a process of single short distance migration flows towards attractive areas. The areas of absorption are areas of positive net migration.

3. Migration is leading to population loss in the areas that are feeding the process of absorption. The areas of dispersion are areas of negative net migration. In these processes the communication facilities are offsetting the deterrence effect of distance or "facilities of communication may frequently the disadvantage of distance."

In fact the second and third "laws" are mirror images of one other: areas of population gain depend on areas of population loss. Ravenstein associates the former with industry and commerce, and the latter with agriculture. Migrations from the areas of dispersion to the areas of absorption were expected to occur in a cascading manner.

4. "Each main current of migration produces a compensating counter-current."

5. "Migrants proceeding long distances generally go by preference to one of the great centres of commerce and industry", or towards today's larger metropolitan areas. 
6. The natives of towns are less migratory than those of the rural parts of the country." Or, residents of urban areas have a lower propensity to migrate than rural residents.

7. "Females are more migratory that males." Or, women have a higher propensity to migrate.

Needless to say, due to the lack of data, the statements about the different inclinations (being "less" and "more migratory") were not based on detailed demographic analysis, but on the observation of frequencies. Nonetheless, Ravenstein argued for a demographic approach taking both the population at origin and destination into account.

Of the seven "laws" put forward by Ravenstein, this paper focuses specifically on the role of two socio-demographic variables: citizenship and sex. We analyse the differences between men and women and between Italians and foreign nationals in relation to international and internal migration and the impact on regional population change. Further items on our checklist are the distance mentioned in several of Ravenstein's "laws" and the socio-economic characteristics of the areas of origin and destination. Even though Ravenstein does not explicitly mention the predominant role of the economic drivers of migration, several references are made to the "great centres of commerce and industry" as well as to rural areas when discussing the direction of migration flows and the processes of absorption and dispersion.

Before discussing the case studies, however, we will give a brief overview of recent trends in international and internal migration and population change in Ita$l y$, and the regional relationship between international and internal migration and population change when comparing the two periods 2004-2008 and 2013-2017 by citizenship, sex, and age group.

From 2002 through 2017, the total population resident in Italy grew from 56.996 to 60.484 million. This increase is entirely due to the foreign component, since the Italian population slightly decreased from 55.646 million at the beginning of 2002 to 55.340 million at the end of 2017. International migration has shaped national and regional demographic change in Italy over the past two decades. Figure 1 presents annual international net migration in relation to the respective population. The foreign population grew from 1.357 million at the beginning of 2002 to 5.144 million at the end of 2017 (5.256 at the end of 2018). For the foreign population, the years when measures to legalise irregular migrants were enacted clearly stand out. For example, the years 2002-2003 - after the Bossi-Fini law (Law 189/2002) came into force - saw the legalisation of the legal status of about 650,000 irregular foreigners who presumably immigrated before 2002-2003. The 2007 EU enlargement brought another important migratory influx, especially from Romania.

The decrease of immigrants after the start of the economic crises and especially after 2010 brought the increase of the number of the foreign nationals resident in Italy to a halt by 2014. Only the arrival of refugees and asylum seekers after 2014 once again led to a slight increase in the international net migration rates.

Linked to the immigration flows, the high internal aggregate net migration rates of the foreign population are indicated in Figure 2. Until 2008, their total internal 
Fig. 1: International net migration rates, Italy 2002-2017 (per 1,000) International net migration rate (per 1,000)

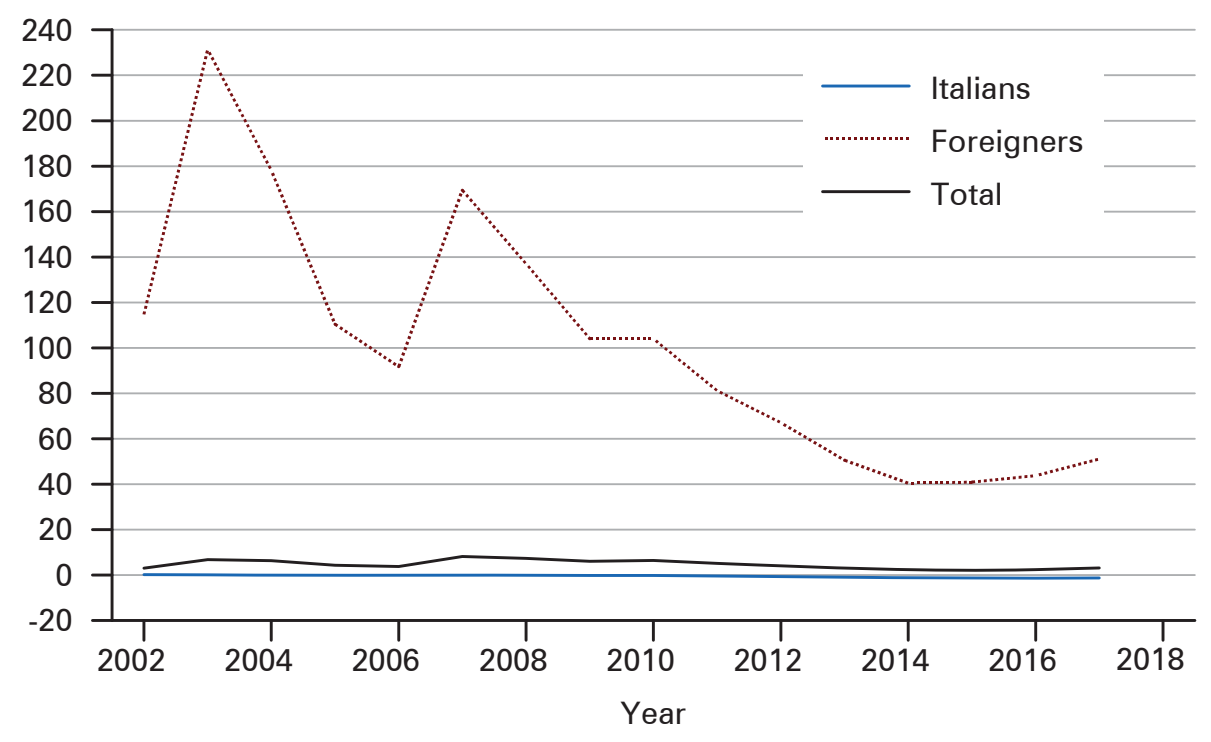

Source: Authors' calculations based on Istat: “Iscrizioni e cancellazioni all'anagrafe per trasferimento di residenza"; population estimates by citizenship, sex and age [http://demo.istat.it/]

migration change was significantly higher than the Italian one and only thereafter values declined to around 3 per mille. Between 2013 and 2017, rates fluctuated between 2 and 3 per mille. As mentioned earlier, the 2012 values are primarily influenced by the changes in administrative procedure, rather than by the economic downturn. The consistently decreasing internal mobility rate of the foreign population brings the total internal aggregate net migration rates to levels more similar to those recorded for the Italian population.

International net migration change is dominated in the first years by the age groups 20-34, whereas in more recent years they have been superseded by the 15-19-year-olds, with increasing migration gains for the 15-19-year-olds and relative decreasing ones for the 30-34-year-olds (Fig. 3).

In fact, since 2014, the characteristics of immigration have changed profoundly: there has been a shift from work-related to family-related immigration. In addition, it should be noted that humanitarian emergencies have played an important role for the migratory inflows. These changes are obviously reflected in the international net migration rates by sex and age. However, it should also be noted that emigration flows might not always be registered properly due to a lack of incentives for people leaving Italy to formally de-register (UNECE/EUROSTAT 2010).

Until 2014, generally (slightly) more foreign women immigrated to Italy than foreign men did (52.6 percent in 2002, 55.4 percent in 2010), but since then their share in immigration flows has declined to 41.6 percent in 2017. In the cases of the immi- 
Fig. 2: Internal aggregate net migration rates, Italy 2002-2017 (per 1,000)

Internal aggregate net migration rate (per 1,000)

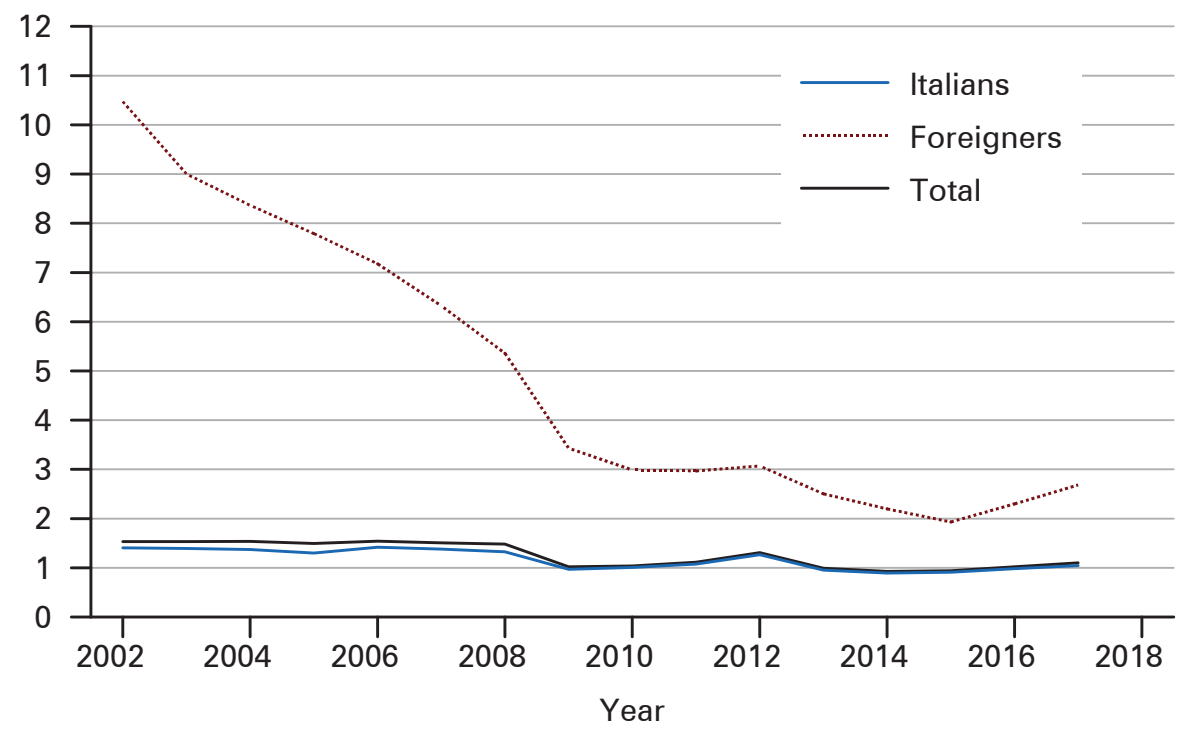

Source: Authors' calculations based on Istat: "Iscrizioni e cancellazioni all'anagrafe per trasferimento di residenza"; population estimates by citizenship, sex and age [http://demo.istat.it/]

gration and emigration of the Italian population, the shares of women are lower than those of men in all years. The internal net migration dynamics are dominated by the 20-34-year-olds, with the highest aggregate net migration rates for the age group 25-29. Whereas an increasing trend is observed for the 25-34-year-olds, the trend for the younger age group $(20-24)$ is decreasing. This is in line with the observation of the continuous postponing of life course events by young adults in Italy (/stat 2014). The overall internal aggregate net migration declined after 2008, most clearly for the young adults, and recovered in the last years.

This paper examines a total of 22 cases in four groups. The first contains the most important Italian metropolitan areas: Milan, Genoa, Bologna, Rome, Naples, Bari and Palermo, with the first four Central-Northern metropolitan areas (except Genoa) being areas of attraction (or "absorption"). The second covers Mezzogiorno LLMAs characterised by migration loss: Isernia, Torre del Greco, Foggia, Melfi, Reggio Calabria, Vibo Valentia, Caltanissetta and Gela. Third, the Tuscan LLMAs of Florence, Livorno ("Leghorn"), Pisa and Prato is taken into account because Ravenstein (1889) referred to them explicitly. Fourth and finally, three "outliers" are considered: Desenzano del Garda on the shores of Lake Garda and Meran in South Tyrol show special patterns of net migration gain over recent years, since they are important tourist destinations, and L'Aquila is of particular interest because it was hit by an earthquake in 2012. 
Fig. 3: International net and internal aggregate net migration rates by age, Italy 2002-2017 (per 1,000)

International migration

International net migration rate (per 1,000)

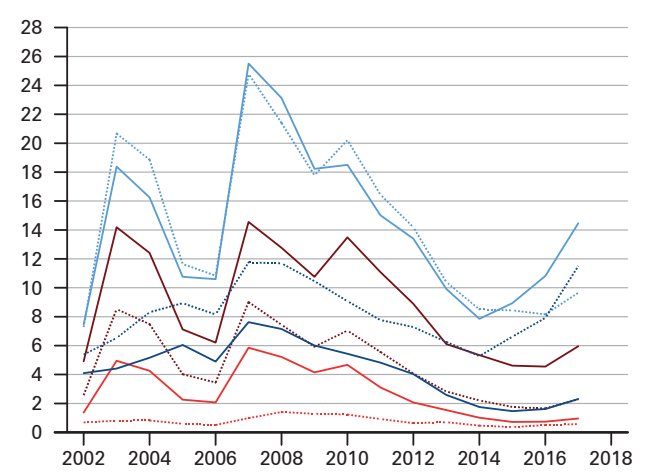

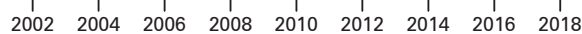
Year
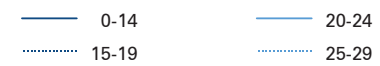

Source: Authors' calculations based on Istat: "Iscrizioni e cancellazioni all'anagrafe per trasferimento di residenza"; population estimates by citizenship, sex and age [http://demo.istat.it/]

Table 1 gives an overview of the case studies, drawing on some basic indicators regarding the settlement structure and the demographic and socio-economic situation. For several indicators, the contrast between Central-Northern and Southern Italy is clearly visible. These include the presence of foreigners, the level of economic activity, and unemployment rates. Another factor that leads to similarities between some of the selected LLMAs is the role of universities. The LLMAs with the highest ratio of enrolled students to the general population are by far Pisa (254 to 1,000 ) and L'Aquila (171), as well as Bologna (96), Florence (77), and Bari (72). This is particularly important for the Tuscan LLMAs, as is the very high share of foreign population. Florence is an international centre attracting many different nationalities, while Prato is one of the centres of Chinese clothing manufacturing in Italy.

Whereas Ravenstein's observations refer to migration flows in a historical period characterised by industrialisation and urbanisation, today's regional patterns of socio-economic disparities in Italy are more varied. The economy is characterised by the continual growth of the service sector rather than manufacturing, whereas the urbanisation process is substituted by locally differentiated processes of sub- and re-urbanisation. The geographic pattern of international net migration 2004-2008 reflects the consistent inflow of migrants in this period and shows that most areas of Central-Northern Italy gained population (Fig. 4), compared to the less attractive Southern areas. The maps presented in Figures 4 and 5 are cartograms in which land area is proportionally rescaled to match each LLMA's 2011 census population, consequently "distorting" their shape. 


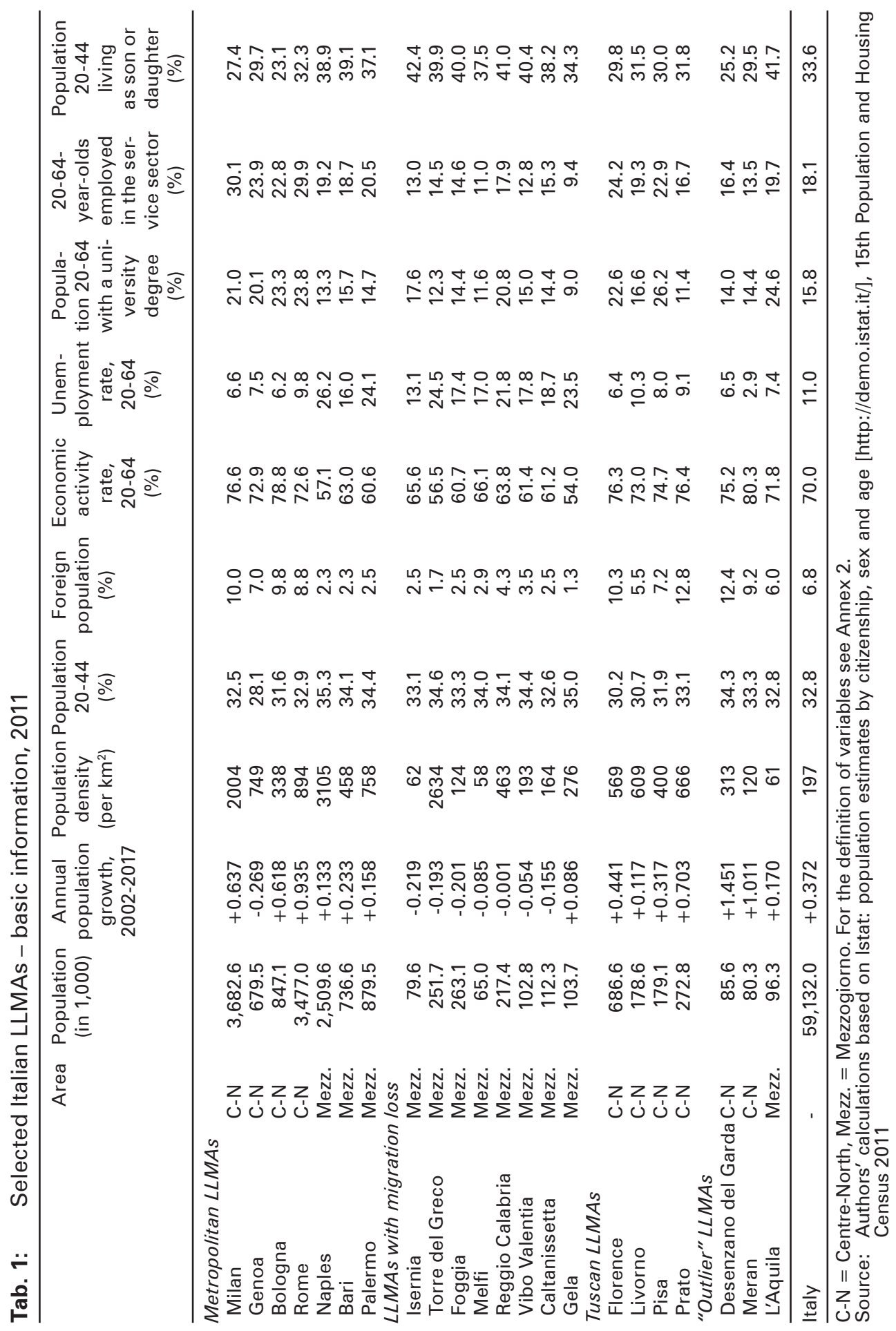


Internal net migration shows the North/South divide of Italy, with most areas of the Mezzogiorno losing population due to internal migration in 2004-2008 and, consequently, most of the Northern LLMAs gaining. Some metropolitan LLMAs of Central-Northern Italy such as Florence, Milan, and Turin also lost population in this period due to internal migration processes, whereas LLMAs adjacent to the metropolitan areas, as well as areas of central Italy, show positive internal net migration rates.

Fig. 4: International and internal net migration rates, Italian LLMAs 2004-2008 $($ per 1,000$)>$
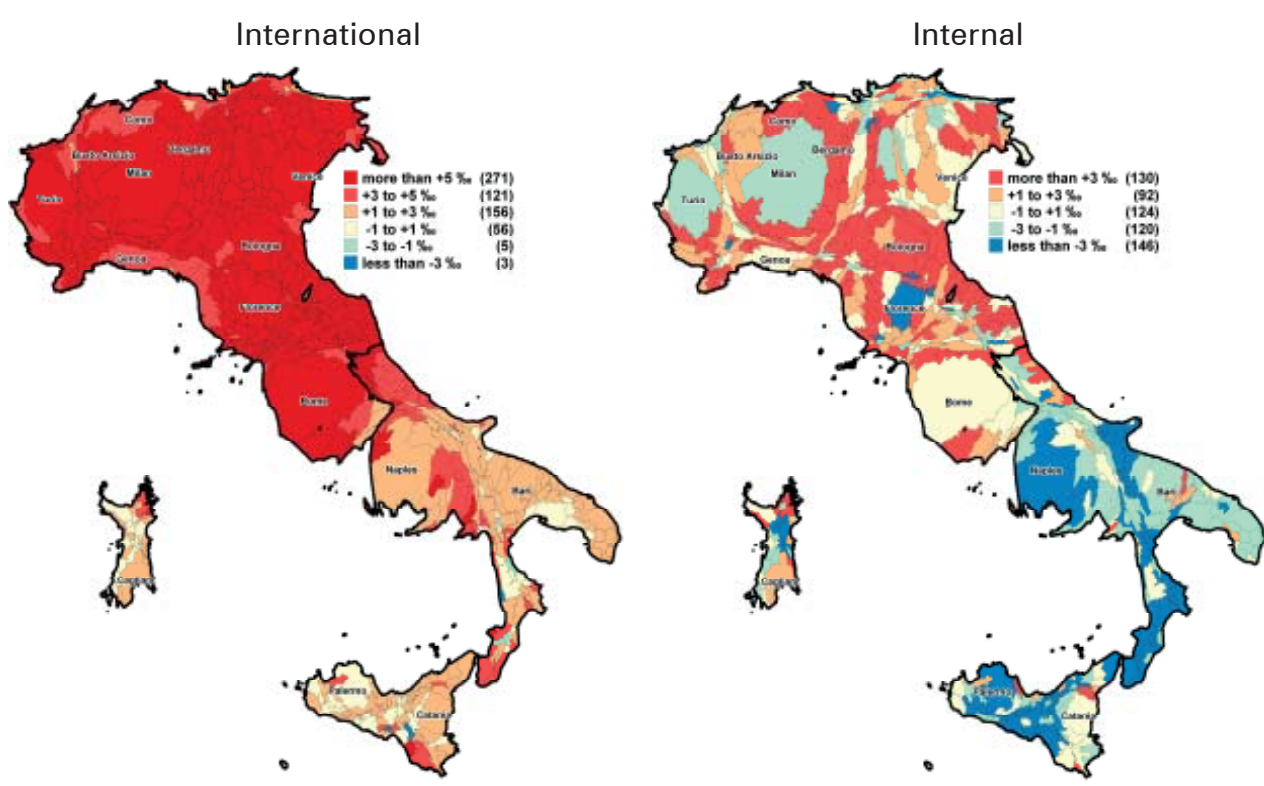

Source: Authors' calculations based on Istat: "Iscrizioni e cancellazioni all'anagrafe per trasferimento di residenza"; population estimates by citizenship, sex and age [http://demo.istat.it/]

From 2013-2017, the geographic pattern of international net migration changes (Fig. 5) was dominated by large net gains in the metropolitan LLMAs such as Milan and adjacent areas, Bologna, Florence, and Rome, and even some smaller LLMAs in the Mezzogiorno. Specific cases such as the LLMAs of Crotone, Isernia, and Ragusa, where some of the reception centres for refugees and asylum seekers are located, appear clearly on the map because they often represent their first residence. Somewhat surprisingly, some smaller LLMAs closer to the Austrian border as well as in the South have lost population due to a negative migration balance. These areas are especially losing young Italian adults because of a lack of economic opportunities. Before the Great Recession, this trend was hardly observed. Internal net migration continues to divide Italy, with the LLMAs of the Mezzogiorno losing and those of Central-Northern Italy almost homogenously moderately gaining population. Only 
Fig. 5: International and internal net migration rates, Italian LLMAs 2013-2017 (per 1,000)

International

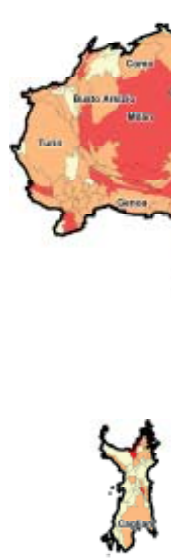

are

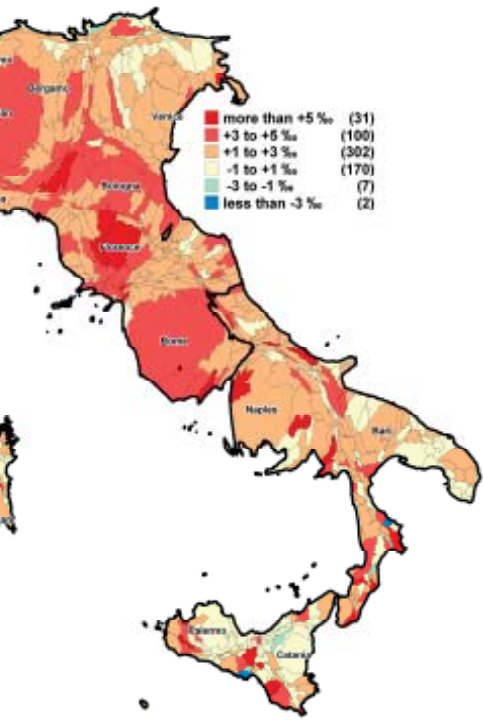

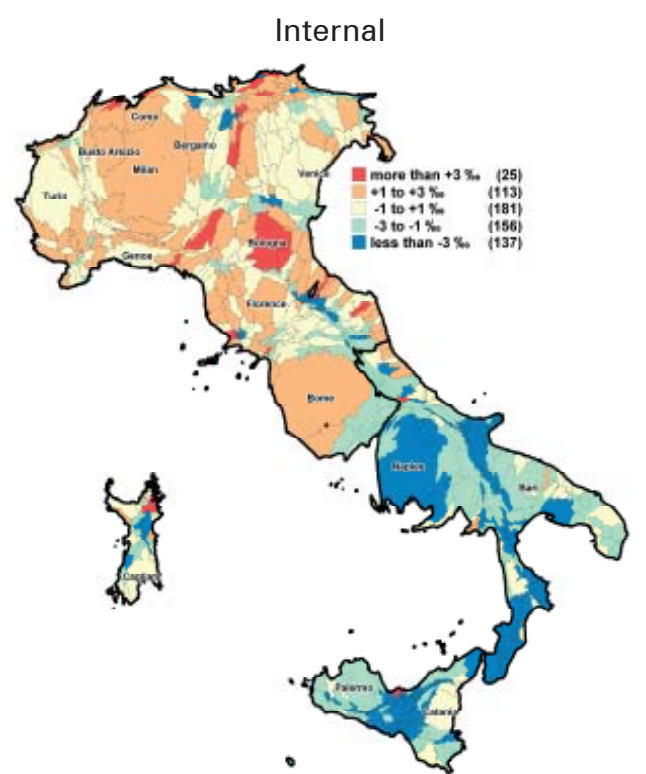

Source: Authors' calculations based on Istat: "Iscrizioni e cancellazioni all'anagrafe per trasferimento di residenza"; population estimates by citizenship, sex and age [http://demo.istat.it/]

the LLMAs of Bologna and Parma, as well as smaller touristic or scenic areas continue to have a positive net migration above 3 per mille.

The general decrease in regional disparities of international and internal net migration between the two periods 2004-2008 and 2013-2017 is worth highlighting. We give an indication of the similarity between the geographic patterns of the net migration rates by LLMA, sex, and international/internal migration by comparing population-weighted correlation coefficients (2011 census LLMA population data). Regarding geographical patterns of international and internal migration, it can be noted that the correlation coefficients between the net migration rates in 2004-2008 are close to +0.450 for the general population as well as for men and women, and in 2013-2017 reach +0.368 in total, +0.186 for men and +0.516 for women. Seemingly the attractiveness of areas is similar comparing the processes of international and internal migration, but by no means identical. Interestingly, the similarity increases between the two periods for women, but diminishes for men.

Comparing the two periods, we note a more intense change in the geographical patterns than expected, since the net rates in the case of international migration for 2004-2008 and 2013-2017 correlate by $+0.520(+0.331$ for men and +0.655 for women) and those for internal migration by $+0.618(+0.590$ for men and +0.637 for women). It would be too easy to attribute these changes solely to the Great Recession, nevertheless it is an indication that changes (but not reversals of geographic patterns) occurred during the study period. 
In general, men and women have very similar geographical patterns of net migration rates: in the case of the internal migration balance, the coefficients are +0.958 in the first and +0.943 in the second period. The patterns are also similar in the case of international moves in the first period $(+0.945)$, but less so in the second one $(+0.678)$ due to the already mentioned relative decrease of the share of women in immigration flows after 2014.

Whereas for 2004-2008 a generally high similarity between the internal net migration rates and the age group-specific ones is observed (over +0.600 for all age groups), in all other cases (international net migration rates of the two periods and internal net migration rates for 2013-2017), the differences in the patterns of the age group-specific net migration rates and the total one are more accentuated and close to zero at the age of retirement. Since most migrants are young adults, their geographic patterns should determine the patterns of the total. Whereas internal net migration in the pre-crises period did show less geographic variability, the geographic patterns of international net migration by age group and for 2013-2017 show a great variability, indicating a variety of factors influencing these patterns.

The migration patterns of the case study LLMAs are summarised in Table 2 and show the existing geographic disparities and the persistence as well as the dynamics of the migration patterns of the LLMAs and over time. All Central-Northern LLMAs have a positive internal migration balance in the second period, except for the

Fig. 6: Correlation coefficients of international and internal net migration rates by age group, 2004-2008 and 2013-201

Correlation coefficients

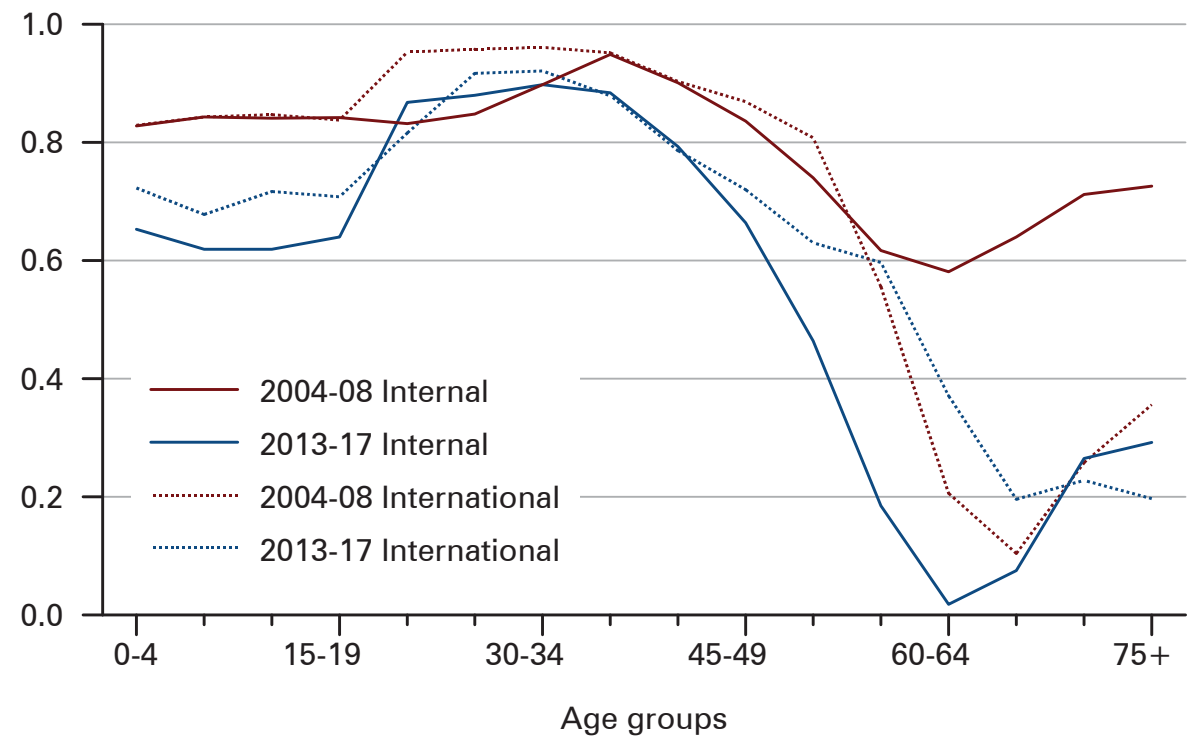

Source: Authors' calculations based on Istat: "Iscrizioni e cancellazioni all'anagrafe per trasferimento di residenza"; population estimates by citizenship, sex and age [http://demo.istat.it/] 


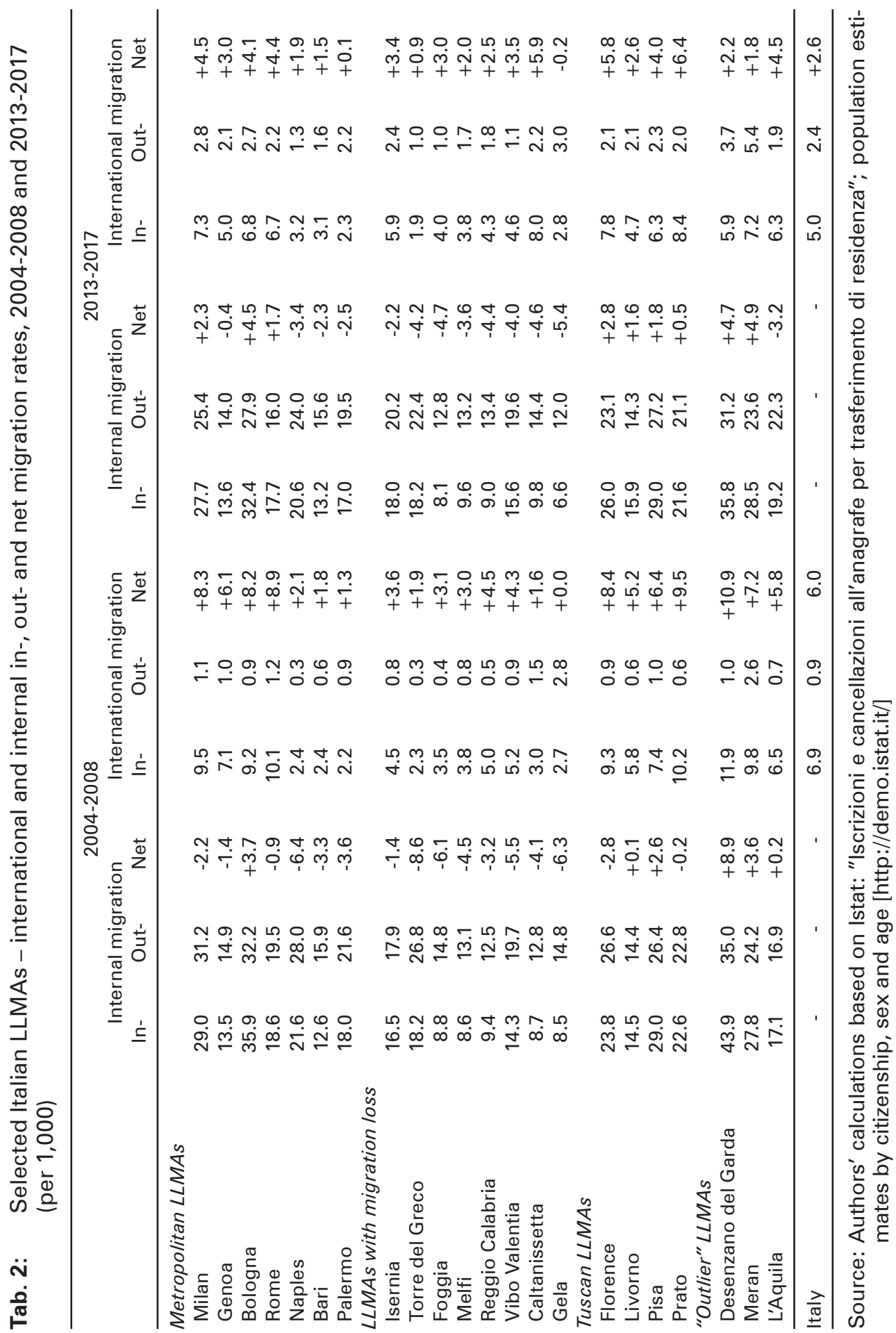


old industrial city of Genoa. It seems that the economic crises amplified the economic weaknesses of the Mezzogiorno, leading to migration gains in the North. The special cases are two attractive tourist destinations and the LLMA of L'Aquila, which was hit by an earthquake in 2009. Regarding international migration, the gains decreased but continued to play an important role in regional population change, contributing to population growth or at least limiting losses due to negative internal net migration.

When observing the single case studies, it is obvious that a great geographic variability exists regarding the impact of internal and international migration on regional population change. Among the selected metropolitan areas, the high migration gain of Milan in 2013-2017 for young adults (Fig. 7a), a turnaround from the internal losses of the earlier period due to sub-urbanisation processes, contrasts with the consistent losses of the LLMA of Naples (Fig. 7c). Bari and Palermo, the other two Southern metropolitan LLMAs, show similar patterns of the process of age selectivity of internal migration. In the region of Rome, similarly to Milan, internal migration gains increased for most age groups between 2004-2008 and 2013-2017 (Fig. 7b). However, migration losses for younger and older persons hint at the persistent selectivity of migration flows. The international migration gains of the Rome LLMA diminished during the study period in all age groups. University towns such as Pisa and Bologna show high migration gains for young adults. Foggia is an example of the other side of the coin: an LLMA that consistently loses young adults and does not even seem to take advantage of return migrants (Fig. 7d). While international immigration leads to a generalised migration gain in all categories, the demographic effect is most impressive in the metropolitan areas of Central-Northern Italy, with extremely high gains for the young foreign adults. In the two periods, all selected LLMAs show a gain from international migration. In some cases the co-location of institutions for persons in search of international protection leads to extremely high, if often only temporary, net migration gains.

Regarding the observation that women have a higher propensity to migrate, we already mentioned that Ravenstein seems not to have conducted his analyses using a reference population or a population at risk. When analysing age-specific patterns of migration intensities (Bonifazi et al 2020), it becomes clear that women anticipate many life events including migratory moves, but that over a lifetime it seems difficult to postulate higher propensities for women in the case of Italy. Only in the case of foreign women an exception was noted in recent years: higher propensities to migrate of older adult women due to their engagement as care providers for individuals and families.

However, focusing on the change of residence from and to the selected seven metropolitan LLMAs, we observe an overall higher propensity to migrate for men (Fig. 8). However, the differences between men and women vary between the LLMAs, between the in-migration and out-migration flows, and between the two periods considered. Italian men consistently seem to migrate more than Italian women. Regarding the foreign population, the patterns completely change between 20042008 and 2013-2017. In the first period, foreign men show a clearly higher propensity to migrate (even though surprising exceptions such as the inflows to the LLMAs 
Fig. 7: International and internal net migration patterns by age-group of selected Italian LLMAs, 2004-2008 and 2013-2017 (per 1,000)

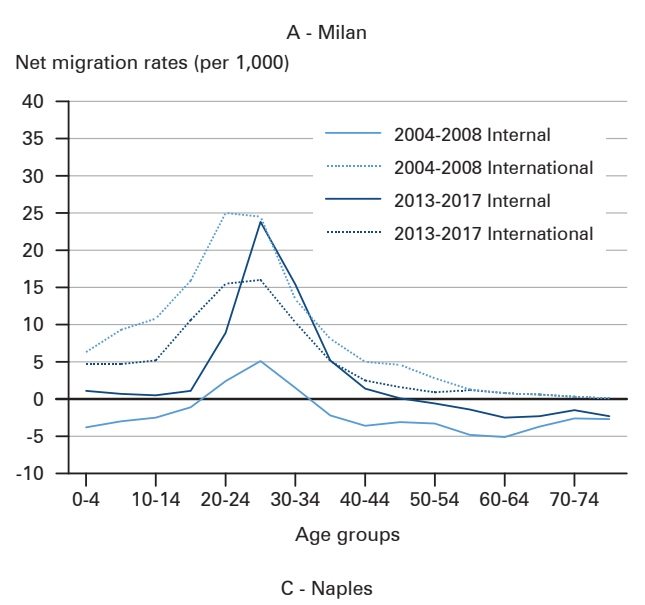

Net migration rates (per 1,000)
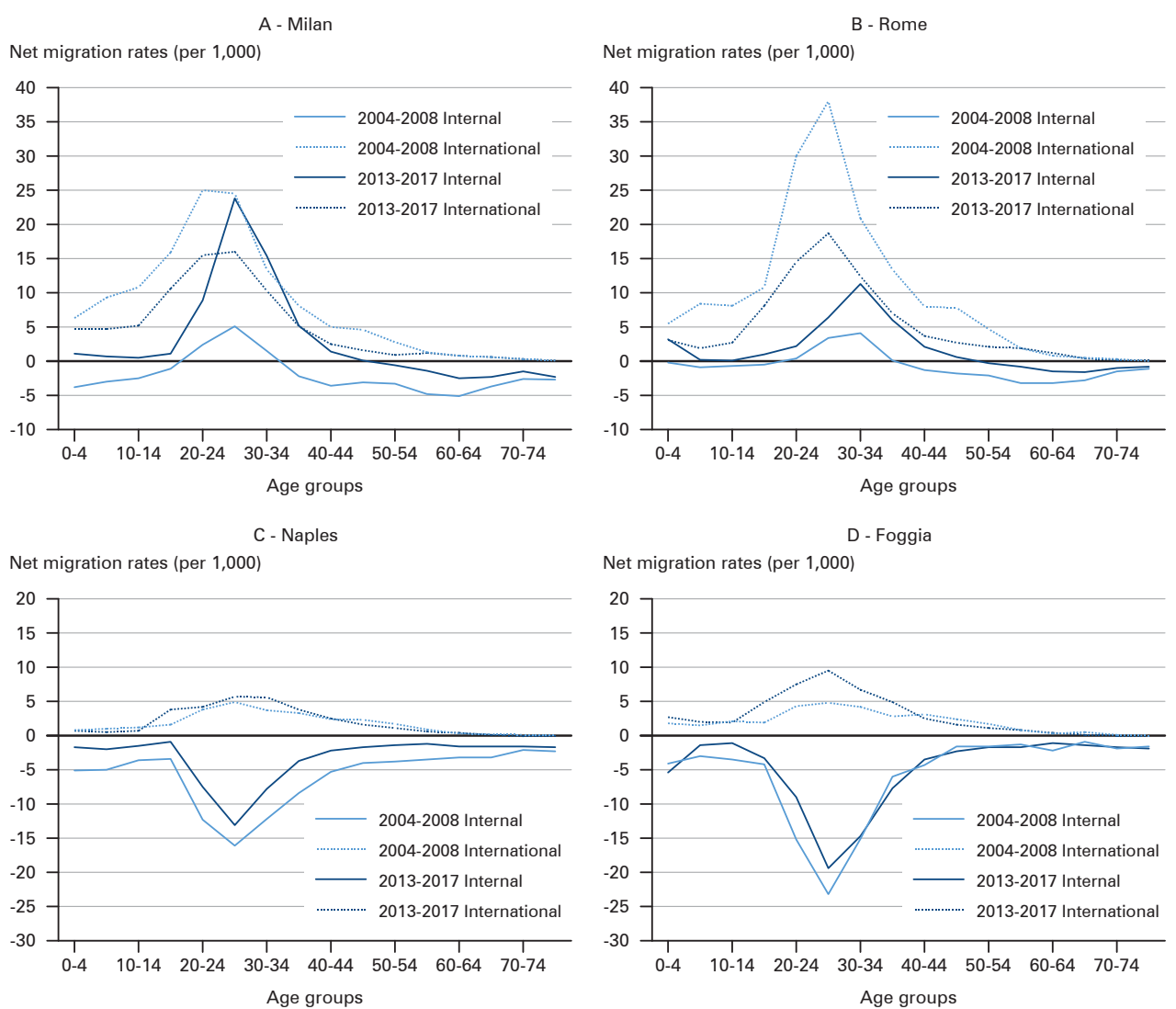

Net migration rates (per 1,000)

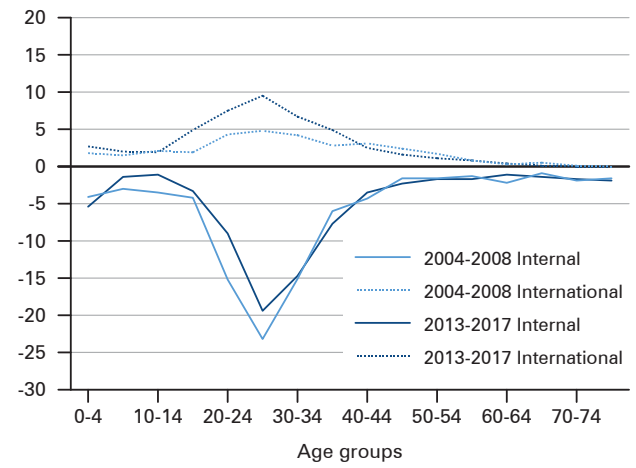

Source: Authors' calculations based on Istat: "Iscrizioni e cancellazioni all'anagrafe per trasferimento di residenza"; population estimates by citizenship, sex and age [http://demo.istat.it/]

of Bari and Genoa are observed). In the second period, the situation changes, as the sex differences are less strong, and women seem to migrate more than men (with the exception of in-migration to Naples and out-migration from Naples and Palermo).

As for the international migration flows (Fig. 9), Italian men migrate more than Italian women. For the foreign population, the immigration rates completely change between 2004-2008 and 2013-2017. The sex distribution varied greatly between LLMAs for 2004-2008 in particular. In the second period, the situation changed and the differences between women and men are more apparent and always in favour of the latter. Regarding the international emigration of foreigners, the LLMAs of the Centre-North show a higher propensity of women, while the opposite is true for the LLMAs of the South in both periods. 
Fig. 8: Internal in-migration and out-migration of the metropolitan Italian LLMAs by citizenship and sex, 2004-2008 and 2013-2017 (per 1,000)
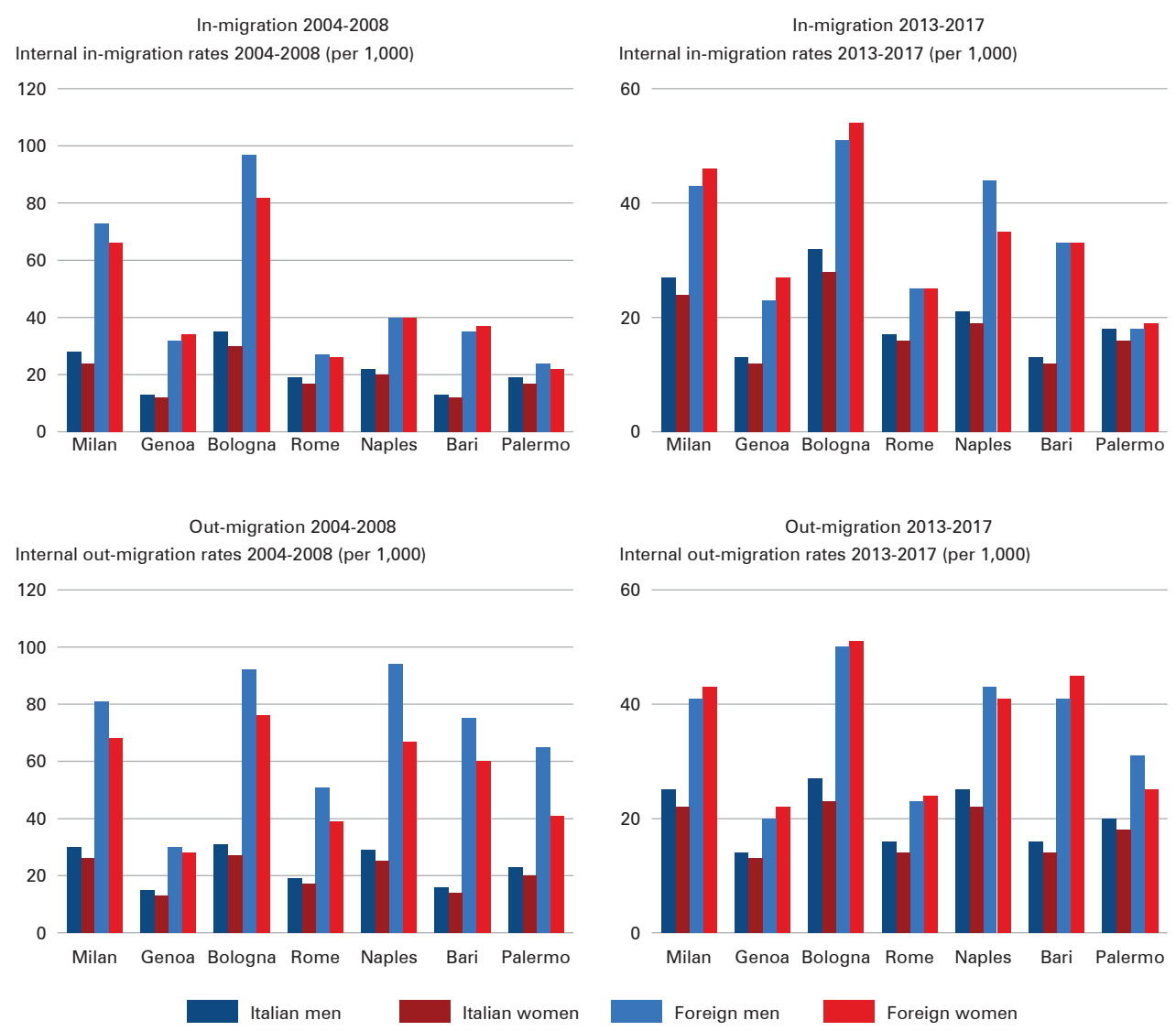

Source: Authors' calculations based on Istat: "Iscrizioni e cancellazioni all'anagrafe per trasferimento di residenza"; population estimates by citizenship, sex and age [http://demo.istat.it/]

The development of the communication and transportation infrastructure and the existing migration networks between the South and the administrative and economic centres of the Centre-North certainly offset the deterrent effect of distance. However, most migrants within Italy still only move a short distance.

Since Italian data on changes of residence refer to the municipality as smallest territorial unit, not all changes of residence over short distances are included in the present analysis. As for Ravenstein, the main focus is on longer-distance migration flows. In 2013-2017, 34 percent of migratory flows took place below the $10 \mathrm{~km}$ threshold (distances of intra-LLMA migration flows are estimated: 1/2 of the radius of the circle with the LLMA's surface area), 72 percent below $50 \mathrm{~km}, 79$ percent below $100 \mathrm{~km}$, and only 13 percent exceed $300 \mathrm{~km}$. This leads to an average migration distance of $115 \mathrm{~km}$ in the $2013-2017$ period in total (slightly down from $121 \mathrm{~km}$ in 
Fig. 9: International immigration and emigration rates of the metropolitan Italian LLMAs by citizenship and sex, 2004-2008 and 2013-2017 (per 1,000)

Immigration 2004-2008

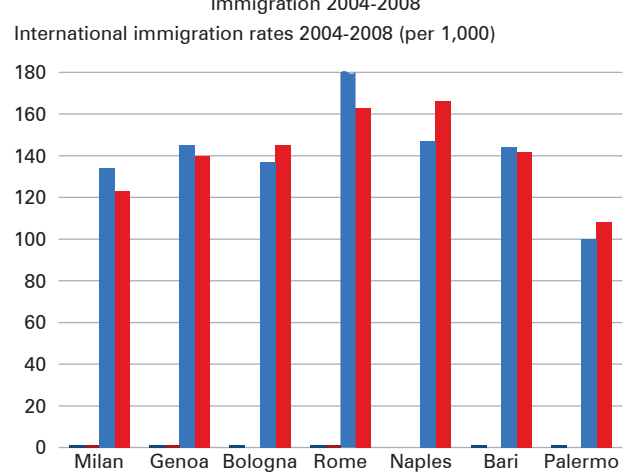

Emigration 2004-2008

International emigration rates 2004-2008 (per 1,000)

12

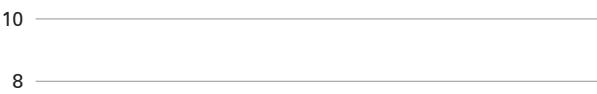

4

Italian men
Immigration 2013-2017

International immigration rates 2013-2017 (per 1,000)

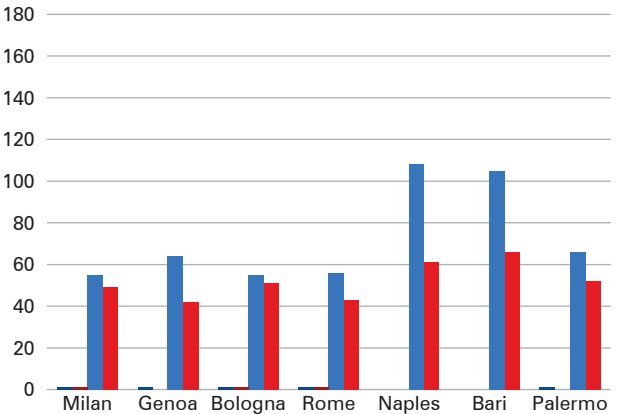

Emigration 2013-2017

International emigration rates 2013-2017 (per 1,000)

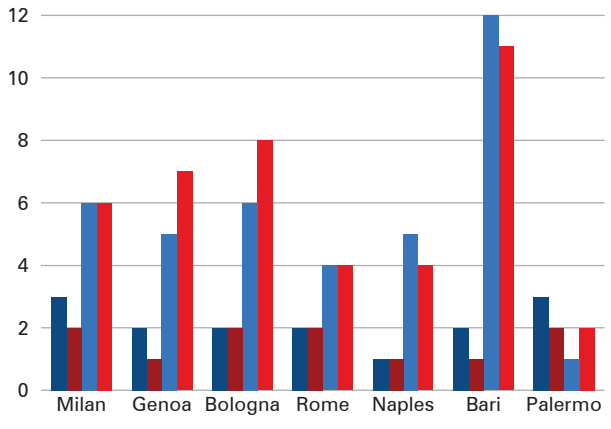

Foreign men

Foreign women

Source: Authors' calculations based on Istat: "Iscrizioni e cancellazioni all'anagrafe per trasferimento di residenza"; population estimates by citizenship, sex and age [http://demo.istat.it/]

2004-2008), $120 \mathrm{~km}$ for Italians and $92 \mathrm{~km}$ for foreign citizens. When excluding the migration flows between municipalities within a single LLMA, the respective values roughly double, leading to an average migratory distance of $211 \mathrm{~km}$, down from $224 \mathrm{~km}$. The average migratory distances range between $95 \mathrm{~km}$ and $135 \mathrm{~km}(179 \mathrm{~km}$ and $244 \mathrm{~km}$ when excluding intra-LLMA changes of residence). Distances increase with age for young people, reaching their highest values for the 25-29-years-olds, then decreasing until the 50-54 age group, followed by another rise, except for 75-year-olds and above. Between 2004-2008 and 2013-2017, the average distances migrated diminished for the under-30-year-olds.

It is certainly true for Italy that most migrants proceed only a short distance, with the important exception of migration flows from the Mezzogiorno to some metro- 
politan areas of the Centre-North, e.g. Turin, Milan, Bologna, or Rome. This confirms Ravenstein's observation that long-distance migrations are usually directed towards the larger metropolitan areas ("great centres of commerce and industry"). For Italy, this observation can be confirmed - at least for the industrial and commercial centres of the Centre-North and for the LLMA of Milan in particular. However, the ubiquity of information and the existence of migratory networks make it easier for internal as well as international migrants to choose the destination they desire, so the concept of the great centres of commerce and industry has to be adapted to the present day realities. Specific functions of an LLMA (higher education, for example) might be of greater importance for attracting long-distance migrants, as well as the presence of specific sub-divisions of the tertiary sectors.

Finally, we analyse socio-economic aspects of Italian international and internal migration patterns following the implicit comments of Ravenstein regarding the drivers of migration when mentioning the "great centres of commerce and industry". Rural areas no longer play a significant role in the migration system due to the decreasing importance of the Italian agricultural sector (Bonifazi/Heins 2000) and the ensuing out-migration from rural areas. Table 3 reports selected results and confirms the importance of the socio-economic dimension (represented by the incidence of the foreign population (\%) and other information of economic wellbeing) for the geographical patterns of net migration rates. Figure 10 shows the two most telling examples: the international net migration rates in 2004-2008 and the internal net migration rates in 2013-2017. Both show a positive relationship between economic activity rates (for the 20-64-year-olds) and net migration rates. The activity rates show a clear difference between the Mezzogiorno (with lower values) and the, on average, economically better-off Central-Northern Italian LLMAs (with higher ones).

International migration gains in the years preceding the economic crises are clearly determined by the economic and labour situation of the LLMAs, although important local variations are observed. These are attributable to the important immigration flows of this period and local labour market specificities regarding, for example, caregiving and the agricultural sector, where many foreigners are employed. In the more recent period (2013-2017), characterised by lower immigration flows, the correlation coefficients are lower. (Clearly, the correlation analysis only assesses a linear relationship between the distributions, a limitation when considering the relationship between net migration rates and socio-economic variables.) Regarding internal net migration, the positive relationship with the activity rates $(+0.580)$ in 2004-2008 intensified in 2013-2017 (+0.788), probably due to lower variability and a clearer linear relationship. In general, the combination of different socio-economic information does not increase the share of the geographic differences of the net migration rates "explained" by them. Based on the role played by population density in the Italian settlement system, it is not surprising that the correlation coefficients are relatively low. In the pre-crises period, a positive migration balance could be observed for mid-sized LLMAs to the detriment of high- and low-density LLMAs. However, the geographical variability is so high that it would be incorrect to define this period as counter-metropolitan or characterised by movement away from 


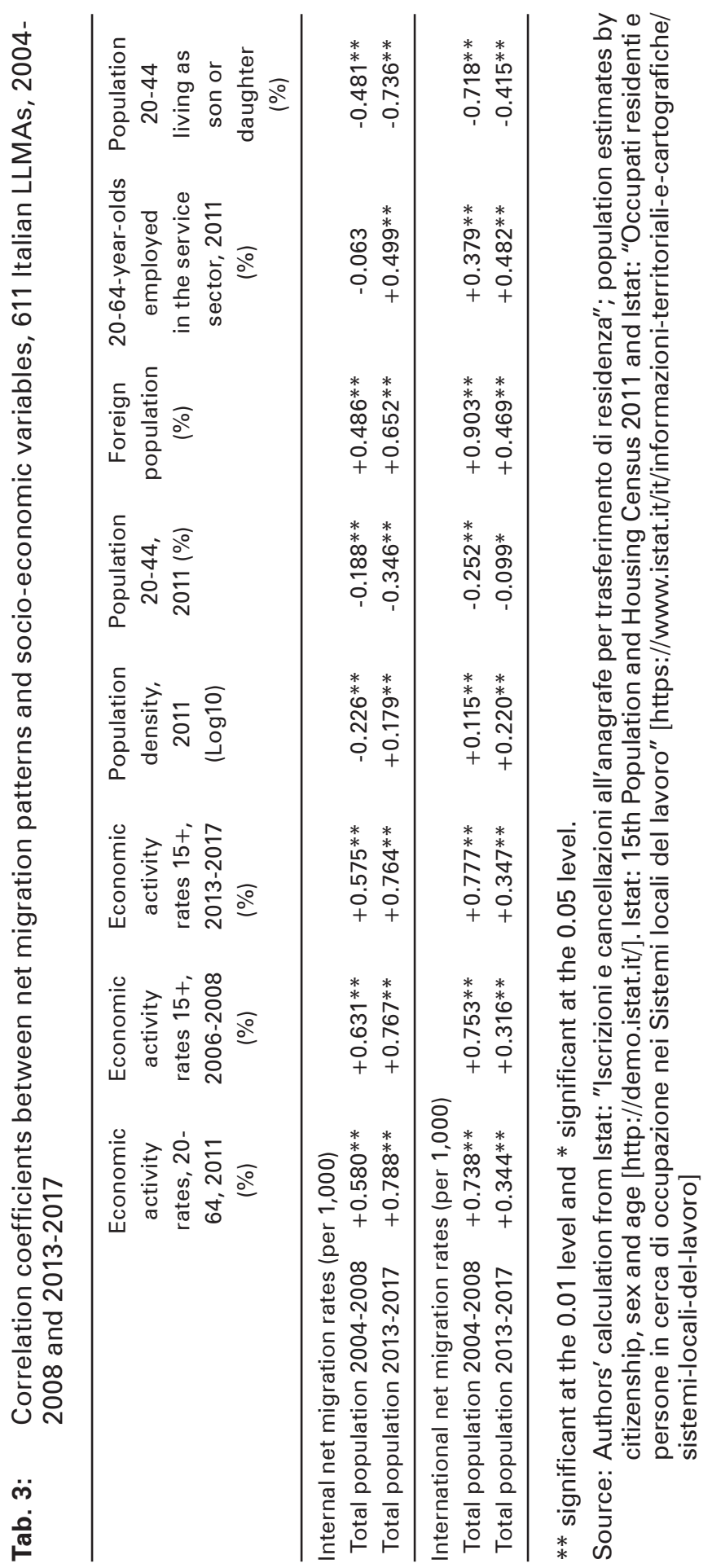


Fig. 10: Two examples of the relationship between net migration rates (per 1,000 ) and economic activity rates (per 100), Italian LLMAs

International net migration rates 2004-2008

International net migration rates 2004-2008 (per 1,000)

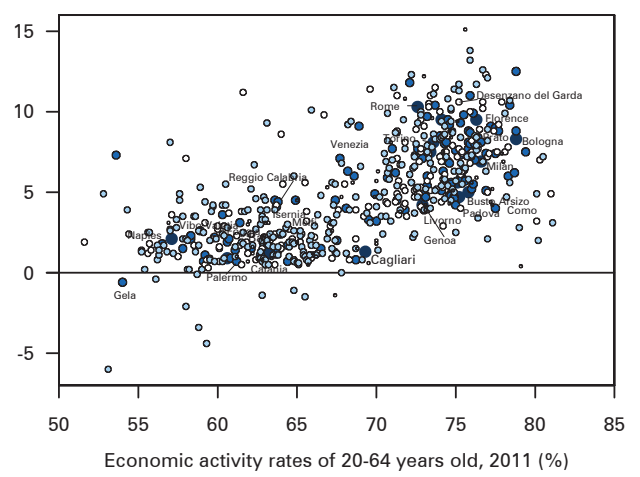

Internal net migration rates 2013-2017

Internal net migration rates 2013-2017 (per 1,000)

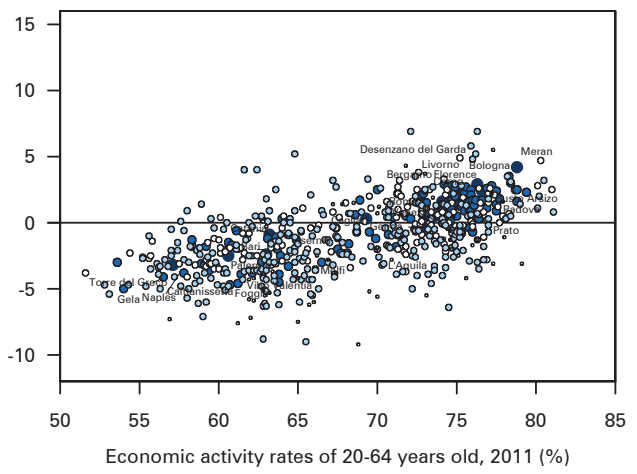

- 500,001 or more residents

$\begin{array}{lll}\text { - } 10,000 \text { residents or less } & \circ 50,001 \text { to } 100,000 \text { residents } \\ \text { - } 10,001 \text { to } 50,000 \text { residents } & \text { - } 100,001 \text { to } 500,000 \text { residents }\end{array}$

Source: Authors' calculations based on Istat: "Iscrizioni e cancellazioni all'anagrafe per trasferimento di residenza"; population estimates by citizenship, sex and age [http://demo.istat.it/]. Istat: 15th Population and Housing Census 2011

metropolitan areas. Rather, employment in the private service sector (along with a general higher level of educational attainment), which is higher in the metropolitan areas of the Centre-North, is positively correlated with net migration rates in 20132017. This is probably an indication that the LLMAs with a higher share of employment in the private service sector were more resilient in the face of recent economic crises, compared to manufacturing-dependent LLMAs. (In a certain way, the discussion regarding population density does apply.) As with the economic variables, the data regarding young adults living with their parents is characterised by a North/ South gradient, with a higher share of 20-44-year-olds living with their parents in the Mezzogiorno and with a lower or negative migration balance (although regional specificities do exist).

Finally, in lieu of a summary, some results of a simple regression analyses of net migration flows between the case study LLMAs and all other LLMAs are discussed. These population-weighted regression analyses for net migration rates for single migration flows use the independent variables listed in Annex 2.

The analyses of the single net migration flows confirm the general patterns already discussed. The quantitatively most important net migration flows and the most unbalanced ones are those to neighbouring LLMAs. For the Milan LLMA, these include Como, Bergamo, Busto Arsizio, Pavia, Crema, Lodi, Lecco, Vigevano; for the Rome LLMA, Pomezia (bordering Rome to the south, it gained 16,200 individuals through the migratory exchange with Rome in 2004-2008, but only 2,000 in 20132017; in total it has the highest volume and net migration in the Italian case), Viterbo, and Rieti; but the same is true also for the Tuscan LLMAs and the other larger LL- 
MAs. Between the two periods (2004-2008 and 2013-2017), the net migration loss of the metropolitan LLMAs diminished significantly, leading to a slowdown of the suburbanisation process. However, in the case of the Southern LLMA of Naples, the net migration loss to Rome and Milan is far more important than the suburban net migration losses to the neighbouring LLMAs of Caserta and Nola. Interestingly, some of the long-distance net migration losses towards the metropolitan LLMAs of Central-Northern Italy increased after the economic downturn. This is especially true for the net migration flows to the advantage of Milan, but also Turin, Florence, and Rome as the largest LLMAs. The interesting case of the net migration flow between Rome and Milan increased in its volume and changed from a quite balanced flow with a slight gain for Milan in the entire first period (about 500 persons) to a net gain of more than 3,100 in the second period. In general, the internal net migration gains increased for Milan between the two periods and the Italian migration system seems to be more focused on Milan today than before the great economic recession, when flows were more balanced and general net migration losses of the metropolitan LLMAs to their surroundings could be observed.

The metropolitan LLMAs of the Mezzogiorno generally only have few net migration flows leading to a net migration gain, mostly these are flows that are linked to their function as regional capitals (Naples, Bari, Palermo, and Reggio Calabria). LLMAs such as Vibo Valentia (Calabria), Caltanissetta and Gela (Sicily) only have negative net migration flows. All these LLMAs have been losing population - especially after the start of the crises - to Milan, Turin, Rome, and the other economic centres of Central-Northern Italy. Traditional links between origins and destinations, such as a preference for the Adriatic corridor for areas in Apulia to Bologna and the Northeast, or Rome and Lombardy for the Sicilian areas, seem to have played a smaller role in 2013-2017. For the Tuscan LLMAs, we observe a net migratory loss only for neighbouring or suburban LLMAs, or even between the LLMAs included here as case studies, such as the net flows between Florence and Prato or Pisa and Livorno, where a turnaround in net gains (or net losses) is observed between the two periods. In the case of Pisa in particular, the presence of installations of the military marine could explain the migratory exchange with places such as La Spezia and Taranto. The two special cases of Desenzano del Garda and Meran are gaining population from their local or regional migration field and through positive net migration flows from Milan, Rome, and Naples. For L'Aquila, an increasing net migration loss to Pescara, as well as Milan and Rome, is observed.

The results of regression models for net migration patterns of single LLMAs are partially inconclusive (Table 4). The adjusted $r^{2}$ of the regression models seems to be too low for drawing reliable conclusions in the great majority of instances. Only in the cases of Milan and Rome do the results seem to be more robust, because their migration field spans the entire nation and the remotest and smallest LLMAs are connected to these centres by some migratory flows.

The differences in the results of the two case studies are certainly due to their geographic locations, for which the differences in the results for the distance parameter are an obvious indication. Moreover, while Milan and Rome are important centres, their roles in the Italian economic and migratory system are different. 
522 - Federico Benassi, Corrado Bonifazi, Frank Heins, Francesca Licari, Enrico Tucci

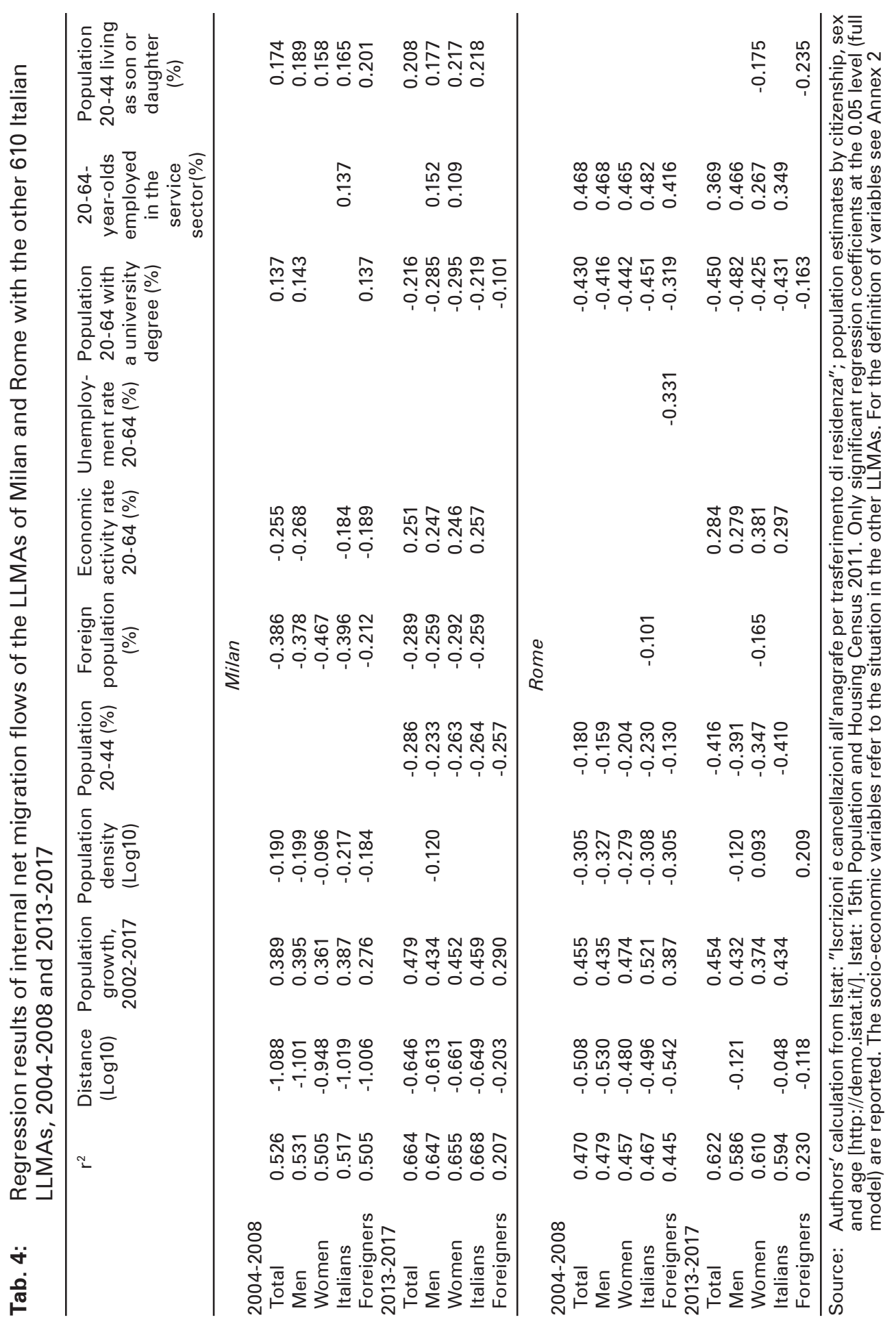


Rome has a more administrative and political, Milan a more economic function. In fact, distance plays a smaller role in the case of Rome. However, the distance parameter is systematically lower in the second period and also has a negative effect (lower migratory gains or losses to areas of high population density disappear in the second period). The regression results linked to population growth and age structure, as well as the presence of the foreign population and the activity rates, reflect general characteristics of areas of migration gains or losses. They do not suggest direct determinants of net migration patterns. Interestingly, the presence of foreign population seems to influence the net migration patterns most strongly in the case of Milan. At the same time, unemployment does not emerge in any case as a factor of migration gains or losses. In general, no fundamental differences between the results for women and men are observed. However, the results for the foreign population seem to indicate different factors that determine the net migration patterns, factors that are not captured through the set of socio-economic variables here.

As observed in another context (Greenwood 2019), individuals, families, and places are heterogenous, and the increasing segmentation of society and the housing and labour markets makes observing generalised migratory behaviour more difficult. The challenge is not only one of analytical precision, but also in the fact that social (and migratory) processes are less "standardised". Greenwood (2019: 273) also offers an interesting discussion regarding the role of differential economic opportunities, such as those in Italy today. However, in the Italian context, the set of potential motivations for internal mobility is so varied and complicated that it seems to have escaped the attention of modellers.

\section{$5 \quad$ Summary of findings}

Ravenstein's empirical approach seems absolutely valid and useful today when applied to present-day Italy, although some of his observations are - naturally - a product of the demographic and socio-economic situation of his times, the geographical setting, and data availability. Regarding migration patterns, Italy seems to present a special case not easily comparable to other European countries. Therefore it would seem inappropriate to expect Ravenstein's 130-year-old "laws" to fully hold when applied to present-day Italy. This contribution attempted to focus on the empirical method followed by Ravenstein, for which he had great sense and sensibility.

Two specific factors predominantly affected recent aspects of Italian migration trends:

First, around the turn of the millennium, international migration flows completely changed the Italian setting. Increasing immigration and the specific migration patterns of the foreign population due to their socially and economically more precarious living conditions (e.g. higher migration intensity, shorter average distance) continue to drive a general change in migration patterns. In addition with the great economic recession, the emigration of Italians is once again playing a role as an alternative to internal migration flows, because internal migration is associated with relatively high indirect and direct costs due to the rigidities of the housing and la- 
bour markets. These circumstances make emigration to study and work in another EU country attractive, while freedom of movement in the EU makes it widely feasible. In recent years, the number of Italian emigrants both less and highly qualified increased, following existing networks of Italians abroad that were created by earlier waves of emigration as well as new destinations.

Second, the growth of the metropolitan LLMAs of Central-Northern Italy seems to have picked up in the wake of the Great Recession, even if this growth is generally more directed to the centres than the peripheries. After an apparent stagnation of internal migration gains, or even losses, in the years up to the crises, these metropolitan areas now again show internal migration gains.

Our results show that more men than women migrate internationally; in the case of internal moves the rates of migration by men and women are similar; internal migration is more important for the foreign than the Italian population; and international migration gains contribute substantially more to overall population change than internal migration gains and losses do.

Not all areas in Italy characterised by high unemployment show an effect of dispersion, and distance does not seem to be a deterrent to migrate. The geographically detailed analysis illustrates the temporal and spatial coexistence of many diverse international and internal migration processes according to local socio-economic characteristics. Notwithstanding the geographic heterogeneity we observe regarding the nexus between the international and internal migration patterns and regional population change, we must acknowledge the importance of the economic and administrative centres of Italy (e.g. Milan, Rome, Naples, and Turin) as the driving force behind the national patterns.

However three main fundamental differences between England in the 1870/1880s and Italy in the 2000s and 2010s exist:

First, the type and detail of migration data are markedly different. Ravenstein could not analyse migration flows in great demographic detail (Greenwood 2019: 276) because the necessary data simply did not exist. For Italy, we were able to show how selective migration flows are - not only regarding sex, but also regarding citizenship and age. Unfortunately, other socio-demographic characteristics of the migrating individuals and families are not so accurate and continue to be difficult to obtain. Obviously the differences between place of birth and register data, discussed in section 2, play a role.

Second, today's demand for labour in Italy is more segmented and specialised, or, in some cases, weaker and more diffuse. The openings of mines or of manufacturing sites that created a demand for unspecific labour in Ravenstein's analysis has long been supplanted regarding international migration by the demand for labour in caregiving, agriculture, and manufacturing - all of which in the Italian case often imply the " 3 D's": dirty, dangerous, and demeaning. In the case of internal migration, labour demand seems to play a minor or less specific role: Since the Great Recession, the low-wage sector has been the only sector with a certain dynamic, but it hardly offers opportunities that would influence internal migration decisions.

Third and finally, knowledge about potential opportunities is now widely available at one's fingertips though modern communication and information technology. 
This includes information about areas of destination and alternatives for internal and international migration.

Even 130 years after their formulation, Ravenstein's migration "laws" are still a valuable starting point in assessing and understanding migration processes and their role in regional population change in Italy. The authors agree with Greenwood's conclusion (2019: 277): “Thus, in general we can conclude that Ravenstein provided a remarkable study of internal migration, the likes of which few have come close to matching." - Including this study.

\section{Acknowledgements}

The authors are very grateful to the editors of the special issue (Prof. Philip Rees and Dr. Nikola Sander) for their support, help and patience. We would also like to thank the two anonymous reviewers for their excellent suggestions, which helped us to improve the paper considerably. We also appreciate very much the thorough and dedicated language editing provided by CPoS.

\section{References}

Alexander, J. Trent; Steidl, Annemarie 2012: Gender and the "Laws of Migration": a reconsideration of Nineteenth-Century Patterns. In: Social Science History 36,2: 223241 [https://doi.org/10.1017/S0145553200011779].

Basile, Roberto; Causi, Marco 2007: Le determinanti dei flussi migratori nelle province italiane: 1991-2001. In: Economia \& Lavoro 41,2: 139-159 [https://doi.org/10.7384/72341].

Basile, Roberto et al. 2018: The impact of immigration on the internal mobility of natives and foreign-born residents: evidence from Italy. In: Spatial Economic Analysis [https://doi.org/10.1080/17421772.2020.1729997].

Bell, Martin et al. 2002: Cross-national comparison of internal migration: issues and measures. In: Journal of the Royal Statistical Society: Series A (Statistics in Society) 165,3: 435-464 [https://doi.org/10.1111/1467-985X.00247].

Benassi, Federico; Heins, Frank; Tucci, Enrico 2019: Residential migrations in Italian metropolitan Local Labour Market Areas: spatial patterns and age-structure effects. In: Canepari, Eleonora; Crisci, Massimiliano (Eds.): Moving Around in Town Practices, Pathways and Contexts of Intra-Urban Mobility from 1600 to the Present Day. Viella Historical Research 15. Roma: Viella: 165-180.

Biagi, Bianca; Dotzel, Kathryn R. 2018: Theoretical advances on interregional migration models. In: Biagi, Bianca et al. (Eds.): New Frontiers in Interregional Migration Research. Advances in Spatial Science. Cham: Springer International: 21-47 [https://doi. org/10.1007/978-3-319-75886-2_2].

Biagi, Bianca; Faggian, Alessandra; McCann, Philip 2011: Long and short distance migration in Italy: the role of economic, social and environmental characteristics. In: Spatial Economic Analysis 6,1: 111-131 [https://doi.org/10.1080/17421772.2010.540035].

Billari, Francesco C.; Liefbroer, Aart C. 2010: Towards a new pattern of transition to adulthood? In: Advances in Life Course Research 15,2-3: 59-75 [https://doi.org/10.1016/j. alcr.2010.10.003]. 
Bonaguidi, Alberto; Terra Abrami, Valerio 1996: The pattern of internal migration: the Italian case. In: Rees, Philip H. et al. (Eds.): Population migration in the European Union. Chichester: John Wiley and Sons: 231-245.

Bonifazi, Corrado 1992: Saldi migratori e studio delle migrazioni. In: Genus 48,1-2: 47-67.

Bonifazi, Corrado (Ed.) 1999: Mezzogiorno e migrazioni interne. Irp-Cnr Monografia 10. Roma: Irp-Cnr.

Bonifazi, Corrado 2013a: L'Italia delle migrazioni. Bologna: II Mulino.

Bonifazi, Corrado 2013b: Mobile per forza. Spostamenti di popolazione nell'Italia della crisi. In: Il Mulino 13,5: 798-805 [https://doi.org/10.1402/74616].

Bonifazi, Corrado; Heins, Frank 2000: Long-term trends of internal migration in Italy. In: International Journal of Population Geography 6,2: 111-131 [https://doi.org/10.1002/ (SICI)1099-1220(200003/04)6:2<111::AID-IJPG172>3.0.CO;2-L].

Bonifazi, Corrado; Heins, Frank 2003: Testing the differential urbanisation model for Italy. In: Tijdschrift voor Economische en Sociale Geografie 94,1: 23-37 [https://doi. org/10.1111/1467-9663.00234].

Bonifazi, Corrado; Heins, Frank 2009: Ancora migranti: la nuova mobilità degli italiani. In: Coorti, Paola; Sanfilippo, Matteo (Eds.): Storia d'Italia. Annali 24. Migrazioni. Grandi Opere. Torino: Giulio Einaudi: 505-528.

Bonifazi, Corrado; Heins, Frank; Tucci, Enrico 2012: Le migrazioni interne degli stranieri al tempo dell'immigrazione. In: Meridiana. Rivista di storia e di scienze sociali 75,3: 173-190 [https://doi.org/10.1400/202294].

Bonifazi, Corrado et al. 2016: Le migrazioni interne in Italia nel 2013-2014: gli aspetti territoriali. In: Colucci, Michele; Gallo, Stefano (Eds.): Fare spazio. Rapporto 2016 sulle migrazioni interne in Italia. Roma: Donzelli: 3-23.

Bonifazi, Corrado; Heins, Frank; Tucci, Enrico 2017: Italy: internal migration in a low-mobility country. In: Champion, Tony; Cooke, Thomas; Shuttleworth, lan (Eds.): Internal Migration in the Developed World. Are we becoming less mobile? Oxon: Routeledge: 242-262.

Bonifazi, Corrado et al 2020: The regional dynamics of internal migration intensities in Italy. In: Population, Space and Place e2331 [https://doi.org/10.1002/psp.2331].

Bubbico, Davide 2012: Le migrazioni interne dal Mezzogiorno tra ricerca di lavoro e mobilità occupazionale. In: Meridiana. Rivista di storia e di scienze sociali 75,3: 149-172 [https://doi.org/10.1400/202292].

Bubbico, Davide; Morlicchio, Enrica; Rebeggiani, Enrico (Eds.) 2011: Su e giù per I'Italia. La ripresa delle emigrazioni interne e le trasformazioni del mercato del lavoro. In: Sociologia del Lavoro 121 [https://doi.org/10.3280/SL2011-121001].

Cellini, Roberto; Torrisi, Gianpiero 2014: Regional resilience in Italy: a very long-run analysis. In: Regional Studies 48,11: 1779-1796 [https://doi.org/10.1080/00343404.20 13.861058].

Champion, Tony 2001: Urbanization, suburbanization, counter-urbanization and re-urbanization. In: Paddison, Ronan (Ed.): Handbook of Urban Studies. London/Thousand Oaks/New Delhi: Sage: 143-161 [https://doi.org/10.4135/9781848608375.n9].

Champion, Tony; Cooke, Thomas; Shuttleworth, lan (Eds.) 2017: Internal migration in the Developed World. Are we becoming less mobile? Oxon: Routeledge.

Coorti, Paola; Sanfilippo, Matteo (Eds.) 2009: Migrazioni. Storia d'Italia. Annali 24. Grandi Opere. Torino: Giulio Einaudi. 
De Filippo, Elena; Strozza, Salvatore 2011: Le migrazioni interne degli stranieri in Italia. In: Sociologia del lavoro 121 (Su e giù per I'Italia - La ripresa delle migrazioni interne e le trasformazioni del mercato del lavoro): 168-195 [https://doi.org/10.3280/SL2011121010].

De Santis, Gustavo 2010: Mobilità a corto e lungo raggio e pendolarismo della popolazione italiana. In: Livi Bacci, Massimo (Ed.): Demografia del capitale umano. Bologna: II Mulino: 123-138.

Faggian, Alessandra; Corcoran, Jonathan; Partridge, Mark 2015: Interregional migration analysis. In: Karlsson, Charlie; Andersson, Martin; Norman, Therese (Eds.): Handbook of research methods and applications in economic geography. Cheltenham: Edward Elgar: 473-495.

Faggian, Alessandra et al. 2018: Regional economic resilience: the experience of the Italian local labor systems. In: The Annals of Regional Science 60,2: 393-410 [https:// doi.org/10.1007/s00168-017-0822-9].

Faggian, Alessandra; Rajbhandari, Isha; Dotzel, Kathryn R. 2017: The interregional migration of human capital and its regional consequences: a review. In: Regional Studies 51,1: 128-143 [https://doi.org/10.1080/00343404.2016.1263388].

Faini, Riccardo et al. 1997: An empirical puzzle: falling migration and growing unemployment differentials among Italian regions. In: European Economic Review 41,3-5: 571 579 [https://doi.org/10.1016/S0014-2921(97)00023-8].

Ferrara, Antonella Rita; Nisticò, Rosanna 2015: Regional well-being indicators and dispersion from a multidimensional perspective: evidence from Italy. In: The Annals of Regional Science 55,2: 373-420 [https://doi.org/10.1007/s00168-015-0704-y].

Fratesi, Ugo; Percoco, Marco 2014: Selective migration, regional growth and convergence: evidence from Italy. In: Regional Studies 48,10: 1650-1668 [https://doi.org/10.1 080/00343404.2013.843162].

Gallo, Stefano 2012: Senza attraversare le frontiere. Le migrazioni interne dall'Unità a oggi. Roma, Bari: Laterza.

Golini, Antonio 1974: Distribuzione della popolazione, migrazioni interne e urbanizzazione in Italia. Roma: Istituto di Demografia, Università di Roma.

Greenwood, Michael J. 2019: The migration legacy of E.G. Ravenstein. In: Migration Studies 7,2: 269-278 [https://doi.org/10.1093/migration/mny043].

Grigg, David B. 1977: E. G. Ravenstein and the "laws of migration". In: Journal of Historical Geography 3,1: 41-54 [https://doi.org/10.1016/0305-7488(77)90143-8].

Impicciatore, Roberto; Strozza, Salvatore 2015: Migrazioni internazionali e interne di italiani e stranieri. In: De Rose, Alessandra; Strozza, Salvatore (Eds.): Rapporto sulla popolazione: I'Italia nella crisi economica. Bologna: II Mulino: 109-140.

Impicciatore, Roberto; Strozza, Salvatore 2016: Internal and international migration in Italy. An integrating approach based on administrative data. In: POLIS 30,2: 211-237 [https://doi.org/10.1424/83908].

Istat 2014: Generazioni a confronto. Come cambiano i percorsi verso la vita adulta. Roma: Istat [https://www.istat.it/it/files/2014/09/Generazioni-a-confronto.pdf, 05.08.2020].

Istat 2015: La nuova geografia dei Sistemi Locali del Lavoro. Letture statistiche - Territorio. Roma: Istat [https://www.istat.it/it/files//2015/10/La-nuova-geografia-dei-sistemi-locali.pdf, 05.08.2020]. 
King, Russel/ 2012: Theories and Typologies of migration: an overview and a primer. Willy Brandt Series of Working Paper in International Migrations and Ethnic Relations 3/12. Malmö: Malmö Institute for Studies of Migration, Diversity and Welfare (MIM), Malmö University [https://www.mah.se/upload/Forskningscentrum/MIM/WB/ WB\%203.12.pdf, 05.08.2020].

Lamonica, Giuseppe Ricciardo; Zagaglia, Barbara 2013: The determinants of internal mobility in Italy, 1995-2006: a comparison of Italians and resident foreigners. In: Demographic Research 29,16: 407-440 [https://doi.org/10.4054/DemRes.2013.29.16].

Lee, Everett S. 1966: A theory of migration. In: Demography 3,1: 47-57 [https://doi. org/10.2307/2060063].

Macisco, John J.; Pryor, Edward T. 1963: A reappraisal of Ravenstein's "Laws" of migration: a review of selected studies of internal migration in the United States. In: The American Catholic Sociological Review 24,3: 211-221 [https://doi.org/10.2307/3708238].

Mocetti, Sauro; Porello, Carmine 2010: How does immigration affect native internal mobility? New evidence from Italy. Working Paper 748. Roma: Banca d'Italia [https:// www.bancaditalia.it/pubblicazioni/temi-discussione/2010/2010-0748/en_tema_748. pdf, 05.08.2020]

Nani, Michele 2013: Alla ricerca di "Leggi delle migrazioni". Ernst Georg Ravenstein (1834-1913) e lo studio della mobilità fra statistica e cartografia. In: Biorci, Grazia; Sinigaglia, Roberto (Eds.): Dialoghi sulle migrazioni. Letteratura, storia e lingua. Genova: Genova University Press: 93-100.

Panichella, Nazareno 2012: Le migrazioni interne nel secolo scorso: vecchie e nuove forme a confronto. In: Stato e mercato 95,2: 255-282 [https://doi.org/10.1425/37882].

Piché, Victor 2013: Contemporary migration theories as reflected in their founding texts. In: Population 68,1: 141-164 [https://doi.org/10.3917/popu.1301.0153].

Piras, Romano 2017: A long-run analysis of push and pull factors of internal migration in Italy. Estimation of a gravity model with human capital using homogeneous and heterogeneous approaches. In: Papers in regional Science 96,3: 571-602 [https://doi. org/10.1111/pirs.12211].

Pugliese, Enrico 2006: L'Italia tra migrazioni internazionali e migrazioni interne. Bologna: II Mulino.

Pugliese, Enrico 2011: Le migrazioni interne nella scena migratoria italiana: novità, persistenze, luoghi comuni. In: Sociologia del lavoro 121 (Su e giù per I'Italia - La ripresa delle migrazioni interne e le trasformazioni del mercato del lavoro): 19-29 [https://doi. org/10.3280/SL2011-121002].

Ravenstein, Ernst Georg 1876: Census of the British Isles, 1871. Birthplace and Migration. In: Geographical Magazine 3, July: 173-177, August: 201-206, September: 229 233 [https://catalog.hathitrust.org/Record/000057985, https://babel.hathitrust.org/ cgi/pt?id=mdp.39015035573404, 03.09.2019].

Ravenstein, Ernst Georg 1885: The Laws of Migration. In: Journal of the Statistical Society 48,2: 167-227 [https://doi.org/10.2307/2979181].

Ravenstein, Ernst Georg 1889: The Laws of Migration - II. In: Journal of the Statistical Society 52,2: 214-301 [https://doi.org/10.2307/2979333].

Rees, Philip et al. 2017: The impact of internal migration on population redistribution: an international comparison. In: Population, Space and Place 23,6 [https://doi. org/10.1002/psp.2036]

Rees, Philip et al. 1998: Internal migration and regional population dynamics in Italy. (Essays 3). Roma: Istat. 
Rowe, Francisco et al. 2019: Impact of Internal Migration on Population Redistribution in Europe: Urbanisation, Counterurbanisation or Spatial Equilibrium? In: Comparative Population Studies 44: 201-234 [https://doi.org/10.12765/CPoS-2019-18en].

Stillwell, John; Thomas, Michael 2016: How far do internal migrants really move? Demonstrating a new method for the estimation of intra-zonal distance. In: Regional Studies, Regional Sciences 3,1: 28-47 [https://doi.org/10.1080/21681376.2015.1109473].

Stouffer, Samuel A. 1960: Intervening opportunities and competing migrants. In: Journal of Regional Science 2,1: 1-26 [https://doi.org/10.1111/j.1467-9787.1960.tb00832.x].

Tobler, Waldo 1995: Migration: Ravenstein, Thornthwaite, and Beyond. In: Urban Geography 16,4: 327-343 [https://doi.org/10.2747/0272-3638.16.4.327].

United Nations Economic Commission for Europe (UNECE), Statistical Office of the European Union (EUROSTAT) 2010: Guidelines for exchanging data to improve emigration statistics. Prepared by the task force on measuring emigration using data collected by the receiving country. Geneva: United Nations [http://www.unece.org/fileadmin/ DAM/stats/publications/Guidelines_improve_emigration_statistics.pdf, 05.08.2020]

Dr. Federico Benassi, Francesca Licari, Dr. Enrico Tucci. Italian National Institute of Statistics. Rome, Italy.

E-mail: benassi@istat.it, licari@istat.it, tucci@istat.it

URL: https://www.researchgate.net/profile/Federico_Benassi

https://www.researchgate.net/profile/Francesca__Licari

https://www.researchgate.net/profile/Enrico_Tucci

Dr. Corrado Bonifazi, Frank Heins $(\bowtie)$. Institute for Research on Population and Social Policies (IRPPS). Rome, Italy.

E-mail: corrado.bonifazi@irpps.cnr.it,frank.heins@irpps.cnr.it

URL: https://www.irpps.cnr.it/en/staff/corrado-bonifazi-3/ https://www.irpps.cnr.it/en/staff/frank-heins-en/ 
530 - Federico Benassi, Corrado Bonifazi, Frank Heins, Francesca Licari, Enrico Tucci

\section{Appendix}

Fig. A1: Map of the case study areas

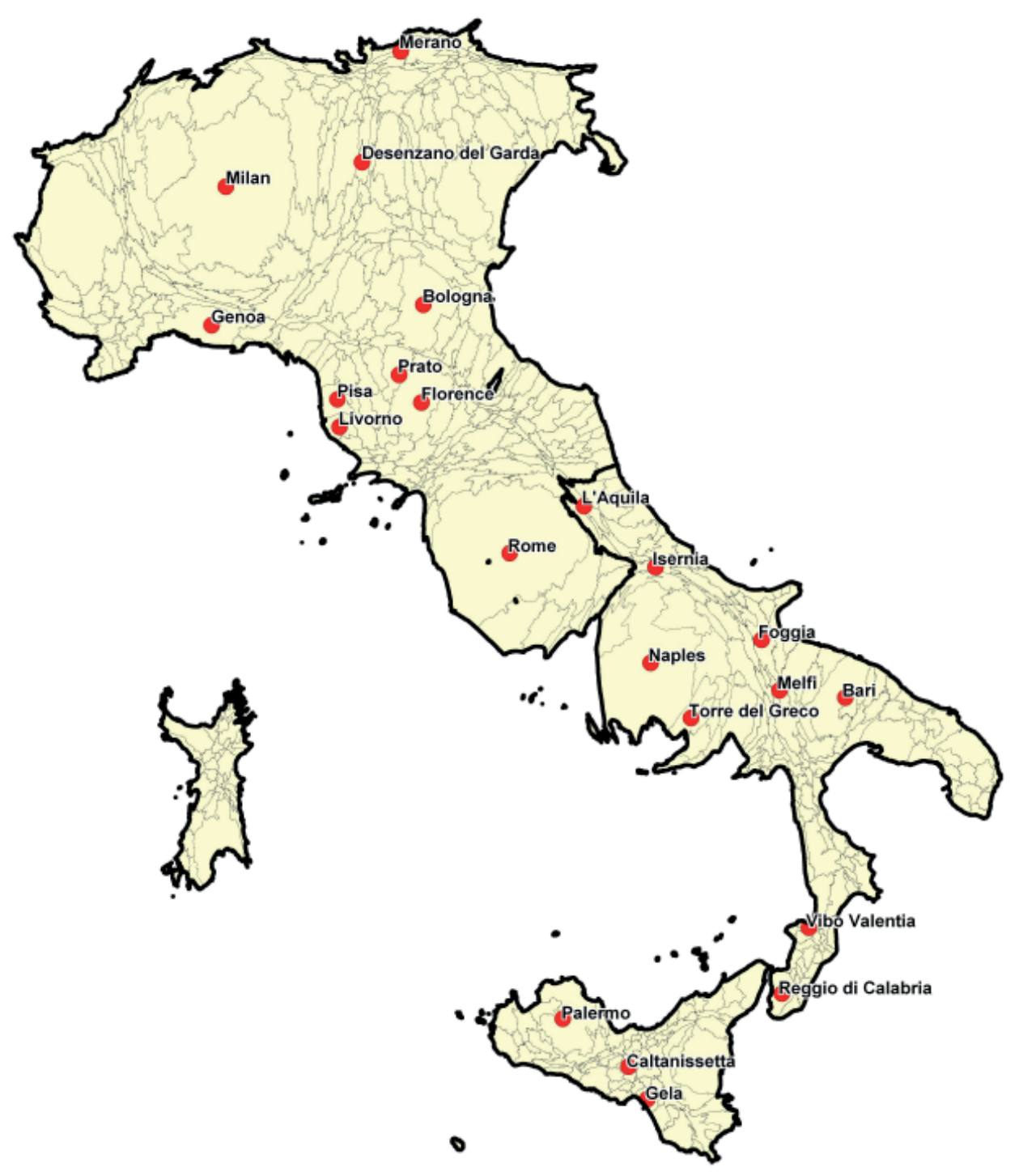

Source: Based on Istat 
Tab. A1: Variables used in the analysis and in Tables 1, 3, and 4

\begin{tabular}{|c|c|c|}
\hline Indicator & Definition & Source \\
\hline Net migration rates & $\begin{array}{l}\text { See section } 3 \text { Data and } \\
\text { Methods }\end{array}$ & Population registers \\
\hline $\begin{array}{l}\text { Economic activity rate } \\
20-64,2011(\%)\end{array}$ & $\begin{array}{l}\text { Share of the 20-64-year- } \\
\text { olds employed and } \\
\text { unemployed }(\%)\end{array}$ & $\begin{array}{l}2011 \text { Population and } \\
\text { Housing Census }\end{array}$ \\
\hline $\begin{array}{l}\text { Economic activity rate } 15+, \\
2006-2008(\%)\end{array}$ & $\begin{array}{l}\text { Share of the over-14- } \\
\text { year-olds employed and } \\
\text { unemployed }(\%)\end{array}$ & $\begin{array}{l}\text { Istat estimates of the } \\
\text { employed and unemployed } \\
\text { in the LLMAs }\end{array}$ \\
\hline Economic activity rate $15+$ & $\begin{array}{l}\text { Share of over-14-year-olds } \\
\text { employed and unemployed } \\
\text { in (average values of } \\
\text { yearly) }\end{array}$ & $\begin{array}{l}\text { Istat estimates of the } \\
\text { employed and unemployed } \\
\text { in the LLMAs [https://www. } \\
\text { istat.it/it/informazioni- } \\
\text { territoriali-e-cartografiche/ } \\
\text { sistemi-locali-del-lavoro] } \\
\text { or [https://www.istat.it/it/ } \\
\text { archivio/217437] }\end{array}$ \\
\hline $\begin{array}{l}\text { Population density } \\
\left(\text { per } \mathrm{km}^{2}\right)\end{array}$ & $\begin{array}{l}\text { Population per surface area } \\
\text { per } \mathrm{km}^{2}\end{array}$ & $\begin{array}{l}2011 \text { Population and } \\
\text { Housing Census }\end{array}$ \\
\hline Population 20-44 (\%) & $\begin{array}{l}\text { Share of the } 20-44 \text {-year- } \\
\text { olds in the total population } \\
(\%)\end{array}$ & $\begin{array}{l}2011 \text { Population and } \\
\text { Housing Census }\end{array}$ \\
\hline Foreign population (\%) & $\begin{array}{l}\text { Share of the foreign } \\
\text { population in the total } \\
\text { population }(\%)\end{array}$ & $\begin{array}{l}2011 \text { Population and } \\
\text { Housing Census }\end{array}$ \\
\hline $\begin{array}{l}\text { 20-64-year-olds employed } \\
\text { in the service sector (\%) }\end{array}$ & $\begin{array}{l}\text { Share of the } 20-64 \text {-year- } \\
\text { olds employed in } \\
\text { service sector (services } \\
\text { for information and } \\
\text { communication, as well } \\
\text { as financial and insurance } \\
\text { activities) }(\%)\end{array}$ & $\begin{array}{l}2011 \text { Population and } \\
\text { Housing Census }\end{array}$ \\
\hline $\begin{array}{l}\text { Population } 20-44 \text { living as } \\
\text { son or daughter }(\%)\end{array}$ & $\begin{array}{l}\text { Share of the } 20-44-y e a r- \\
\text { olds living in a household } \\
\text { as child }(\%)\end{array}$ & $\begin{array}{l}2011 \text { Population and } \\
\text { Housing Census }\end{array}$ \\
\hline $\begin{array}{l}\text { Annual population growth } \\
2002-2017\end{array}$ & $\begin{array}{l}\text { Average population growth } \\
\text { from 01.01.2002-31.12.2017 } \\
(\%)\end{array}$ & Population registers \\
\hline $\begin{array}{l}\text { Unemployment rate } 20-64 \\
(\%)\end{array}$ & $\begin{array}{l}\text { Share of the } 20-64 \text {-year- } \\
\text { olds unemployed as a } \\
\text { share of those that are } \\
\text { employed and unemployed } \\
(\%)\end{array}$ & $\begin{array}{l}2011 \text { Population and } \\
\text { Housing Census }\end{array}$ \\
\hline $\begin{array}{l}\text { Population 20-64 with an } \\
\text { university degree (\%) }\end{array}$ & $\begin{array}{l}\text { Share of the } 20-64 \text {-year- } \\
\text { olds with an university } \\
\text { degree }(\%)\end{array}$ & $\begin{array}{l}2011 \text { Population and } \\
\text { Housing Census }\end{array}$ \\
\hline
\end{tabular}




\section{Comparative Population Studies}

WWW.comparativepopulationstudies.de

ISSN: 1869-8980 (Print) - 1869-8999 (Internet)

\section{Published by}

Prof. Dr. Norbert F. Schneider

Federal Institute for Population Research D-65180 Wiesbaden / Germany

\section{(c) BY-SA}

2019

\section{Managing Editor \\ Prof. Philip Rees \\ Dr. Katrin Schiefer}

\section{Copy Editor}

Julia Luther

\section{Editorial Assistant}

Beatriz Feiler-Fuchs

Wiebke Hamann

\section{Layout \\ Beatriz Feiler-Fuchs \\ E-mail:cpos@bib.bund.de}

\section{Scientific Advisory Board}

Karsten Hank (Cologne)

Michaela Kreyenfeld (Berlin)

Marc Luy (Vienna)

Natalie Nitsche (Vienna)

Peter Preisendörfer (Mainz)

Zsolt Spéder (Budapest)

Rainer Wehrhahn (Kiel)

\section{Board of Reviewers}

Martin Abraham (Erlangen)

Laura Bernardi (Lausanne)

Hansjörg Bucher (Bonn)

Claudia Diehl (Konstanz)

Andreas Diekmann (Zurich)

Gabriele Doblhammer-Reiter (Rostock)

Jürgen Dorbritz (Wiesbaden)

Anette Eva Fasang (Berlin)

E.-Jürgen Flöthmann (Bielefeld)

Alexia Fürnkranz-Prskawetz (Vienna)

Beat Fux (Salzburg)

Joshua Goldstein (Berkeley)

Sonja Haug (Regensburg)

Hill Kulu (Liverpool)

Aart C. Liefbroer (The Hague)

Kurt Lüscher (Konstanz)

Emma Lundholm (Umeå)

Nadja Milewski (Rostock)

Dimiter Philipov (Vienna)

Roland Rau (Rostock)

Tomáš Sobotka (Vienna)

Jeroen Spijker (Barcelona)

Olivier Thévenon (Paris)

Helga de Valk (Brussels)

Heike Trappe (Rostock)

Michael Wagner (Cologne) 